\title{
Depth-dependent geochemical and microbiological gradients in Fe(III) deposits resulting from coal mine-derived acid mine drainage
}

\author{
Justin S. Brantner ${ }^{1,2+}$, Zachary J. Haake ${ }^{3+}$, John E. Burwick ${ }^{3}$, Christopher M. Menge ${ }^{4}$, \\ Shane T. Hotchkiss ${ }^{1}$ and John M. Senko ${ }^{1,2,3 *}$
}

${ }^{1}$ Department of Biology, The University of Akron, Akron, OH, USA

2 Integrated Bioscience Program, The University of Akron, Akron, OH, USA

${ }^{3}$ Department of Geosciences, The University of Akron, Akron, $\mathrm{OH}, \mathrm{USA}$

${ }^{4}$ Department of Chemistry, The University of Akron, Akron, OH, USA

\section{Edited by:}

Kurt O. Konhauser, University of

Alberta, Canada

Reviewed by:

Jeffrey G. Catalano, Washington

University in St. Louis, USA

Danielle Fortin, University of

Ottawa, Canada

*Correspondence:

John M. Senko, Department of

Geosciences, The University of

Akron, 126 Crouse Hall, Akron,

$\mathrm{OH}$ 44325-4101, USA

e-mail:senko@uakron.edu

${ }^{\dagger}$ These authors have contributed equally to this work.
We evaluated the depth-dependent geochemistry and microbiology of sediments that have developed via the microbially-mediated oxidation of $\mathrm{Fe}(\mathrm{II})$ dissolved in acid mine drainage (AMD), giving rise to a $8-10 \mathrm{~cm}$ deep "iron mound" that is composed primarily of $\mathrm{Fe}(\mathrm{III})$ (hydr)oxide phases. Chemical analyses of iron mound sediments indicated a zone of maximal Fe(III) reducing bacterial activity at a depth of approximately $2.5 \mathrm{~cm}$ despite the availability of dissolved $\mathrm{O}_{2}$ at this depth. Subsequently, $\mathrm{Fe}(\mathrm{II})$ was depleted at depths within the iron mound sediments that did not contain abundant $\mathrm{O}_{2}$. Evaluations of microbial communities at $1 \mathrm{~cm}$ depth intervals within the iron mound sediments using "next generation" nucleic acid sequencing approaches revealed an abundance of phylotypes attributable to acidophilic Fe(II) oxidizing Betaproteobacteria and the chloroplasts of photosynthetic microeukaryotic organisms in the upper $4 \mathrm{~cm}$ of the iron mound sediments. While we observed a depth-dependent transition in microbial community structure within the iron mound sediments, phylotypes attributable to Gammaproteobacterial lineages capable of both Fe(II) oxidation and Fe(III) reduction were abundant in sequence libraries (comprising $\geq 20 \%$ of sequences) from all depths. Similarly, abundances of total cells and culturable Fe(II) oxidizing bacteria were uniform throughout the iron mound sediments. Our results indicate that $\mathrm{O}_{2}$ and $\mathrm{Fe}(\mathrm{III})$ reduction co-occur in AMD-induced iron mound sediments, but that Fe(II)-oxidizing activity may be sustained in regions of the sediments that are depleted in $\mathrm{O}_{2}$.

Keywords: acid mine drainage, $\mathrm{Fe}$ (II) oxidizing bacteria, $\mathrm{Fe}$ (III) reducing bacteria

\section{INTRODUCTION}

In the Appalachian coal mining regions of the northeastern United States, acid mine drainage (AMD) arises when coal seamassociated iron sulfide phases are exposed to $\mathrm{O}_{2}$-rich fluids during or upon completion of mining activities (Baker and Banfield, 2003). Biogeochemical reactions in the subsurface between $\mathrm{O}_{2}$ and $\mathrm{FeS}$ phases result in $\mathrm{O}_{2}$-depleted, acidic fluids (typically $\mathrm{pH}$ 2.5-4.0 in the Appalachian coal mining regions) that contain high concentrations of sulfate, $\mathrm{Fe}(\mathrm{II})$, and other metals (Cravotta, 2008). Several systems have been identified in the Appalachian coal mining regions in which AMD emerges at the terrestrial surface and flows as a sheet with a depth of $0.5-1.0 \mathrm{~cm}$ (Senko et al., 2008; DeSa et al., 2010; Brown et al., 2011; Senko et al., 2011; Gouin et al., 2013). This flow regime enhances aeration of the fluids, and consequently the activities of acidophilic, aerobic $\mathrm{Fe}(\mathrm{II})$ oxidizing bacteria (FeOB). While abiotic $\mathrm{Fe}(\mathrm{II})$ oxidation is kinetically limited at the $\mathrm{pH}$ encountered in Appalachian coal mine-derived AMD-impacted systems, the solubility of Fe(III) is low, such that hydrolysis and precipitation of $\mathrm{Fe}(\mathrm{III})$ (hydr)oxides occurs (Regenspurg et al., 2004; Senko et al., 2008; DeSa et al.,
2010; Brown et al., 2011; Gouin et al., 2013). With sustained emergence of $\mathrm{AMD}, \mathrm{FeOB}$ activities give rise to massive deposits (tens to hundreds of $\mathrm{cm}$ deep) that are composed almost exclusively of biogenic Fe(III) (hydr)oxides and are referred to as "iron mounds" (Senko et al., 2008; Brown et al., 2011; Gouin et al., 2013). At an iron mound located in eastern Ohio (referred to as "The Mushroom Farm" or MF), we have observed the oxidative precipitation of approximately $10 \mathrm{mM}$ Fe over a distance of $30 \mathrm{~m}$ after AMD emergence at the terrestrial surface (Gouin et al., 2013). At the MF system and elsewhere, iron mounds develop with no human intervention (Senko et al., 2008; DeSa et al., 2010; Brown et al., 2011; Gouin et al., 2013), so it has been proposed that engineered systems mimicking the sheet flow characteristics of iron mounds could be exploited for the inexpensive and sustainable removal of dissolved Fe(II) from AMD (Senko et al., 2008; DeSa et al., 2010; Brown et al., 2011), which remains the greatest threat to surface water quality in Appalachia (US EPA, 2006).

The Fe(III) hydroxides in iron mounds may accumulate quite rapidly. For instance, at the MF system, AMD began flowing 
over formerly pristine soil approximately 20 years ago (Cheryl Socotch, personal communication), and since then, a $8-10 \mathrm{~cm}$ thick Fe(III) (hydr)oxide crust has developed, indicating an iron mound "growth rate" of $0.4-0.5 \mathrm{~cm} /$ year. This rapid accumulation of Fe(III) (hydr)oxides poses a challenge to microorganisms mediating the oxidative precipitation of Fe. An implication of the rapid accumulation of $\mathrm{Fe}$ (III) (hydr)oxide precipitates is that the microorganisms mediating oxidative precipitation of Fe may become buried in $\mathrm{Fe}$ (III) phases that they produce. Similarly, $\mathrm{O}_{2}$ is likely to be depleted at the constantly rising sediment-water interface, giving rise to anoxic zones within the sediments. Anaerobic metabolism within iron mound sediments is likely to be predominantly $\mathrm{Fe}$ (III) or sulfate respiration (Burton et al., 2007; Sánchez-Andrea et al., 2011). These activities may be considered detrimental to the overall goal of oxidative precipitation of $\mathrm{Fe}$, since these activities could result in the reductive re-release of $\mathrm{Fe}(\mathrm{II})$, or concentration of FeS phases near the terrestrial surface, which, if subsequently oxidized upon intrusion of $\mathrm{O}_{2}$, would result in release of more concentrated AMD (Johnson and Hallberg, 2002). However, the depthdependent geochemical gradients and associated distributions of microorganisms in iron mounds and physicochemically similar systems remain unclear. As such, we evaluated the chemistry and microbiology at $\leq 1 \mathrm{~cm}$ depth intervals within the MF iron mound.

\section{MATERIALS AND METHODS SITE DESCRIPTION AND FIELD SAMPLING}

The MF AMD-impacted system is located in North Lima, Mahoning County, $\mathrm{OH}\left(40^{\circ} 56^{\prime} 09^{\prime \prime} \mathrm{N}, 80^{\circ} 40^{\prime} 04^{\prime \prime} \mathrm{W}\right)$. AMD from an abandoned subsurface mine has filled the basement of a nowvacant house, from which it emerges with $\mathrm{pH} 4.2$ and $12 \mathrm{mM}$ $\mathrm{Fe}(\mathrm{II})$ (Gouin et al., 2013). AMD that emerges from the basement window well of the vacant house flows as a sheet over the terrestrial surface, which has given rise to an iron mound covering an area of approximately $45 \mathrm{~m}^{2}$ (Gouin et al., 2013) that is composed of $7 \mathrm{mmol} \mathrm{Fe} / \mathrm{g}$ (75\% Fe(III) phases by mass, if $\mathrm{Fe}(\mathrm{OH})_{3}$ is assumed; Bertel and Senko, unpublished). All measurements and sample collection were conducted in a $0.5 \mathrm{~m}^{2}$ portion of the iron mound located approximately $6 \mathrm{~m}$ from AMD emergence. AMD continuously flows throughout the year as a sheet over this portion of the iron mound. A series of cores were collected from this region using $60 \mathrm{cc}$ syringes with the leur ends removed. Upon recovery of the cores, they were covered with plastic wrap, sealed with vinyl tape, and placed on ice for transport to the laboratory, where they were extruded at approximately $1 \mathrm{~cm}$ intervals for subsequent mineralogical analysis by X-ray diffraction (XRD) and quantification of solidassociated $\mathrm{Fe}(\mathrm{II})$, total organic carbon (TOC), and total nitrogen (described below). Passive porewater samplers similar to those described by Spaulding and Brooks (2005) were prepared by melting agarose $(5 \%)$ in deionized water with $1 \mathrm{mM} \mathrm{KBr}$, which served as a tracer to determine complete equilibration of passive sampler fluid with the surrounding iron mound porewater. To cast the samplers, molten agarose was solidified within 60 cc syringes with the leur ends removed. The resulting agarose cylinders (referred to as "plugs") with internal dimensions of the
$60 \mathrm{cc}$ syringes were subsequently inserted into holes left behind by coring. Two passive sampling plugs were deployed. Passive sampling "plugs" were incubated in the iron mound for one month before recovery, at which point, they had swelled to fill the entire void left behind by coring. Passive sampler "plugs" were transported to the laboratory and sectioned at $0.5 \mathrm{~cm}$ intervals before quantification of dissolved $\mathrm{Fe}$ (II) and sulfate (described below).

Cores used for microbial enumerations were collected in the same fashion, except that syringes were autoclaved and cores were covered with sterile aluminum foil for transport to the laboratory on ice. Core for nucleic acid-based microbial community analysis was collected using a sterile polypropylene core liner with a diameter of $2.5 \mathrm{~cm}$. Cores intended for microbial enumerations were stored at $4^{\circ} \mathrm{C}$ for no more than 1 week before enumerations were initiated (described below). The core intended nucleic acidbased microbial community analysis was stored at $-80^{\circ} \mathrm{C}$ before further processing (described below).

\section{ANALYTICAL TECHNIQUES}

After sectioning, passive sampling "plugs," $0.5 \mathrm{~cm}$ sections were divided into quadrants. One quadrant was ground with a spatula and suspended in purified water for extraction of plugassociated sulfate and bromide, while a second quadrant was treated identically, except that it was suspended in $0.5 \mathrm{M} \mathrm{HCl}$ for extraction of plug-associated Fe(II). Plug-fluid suspensions were incubated overnight at room temperature, solids were removed from fluid by centrifugation, and aqueous sulfate (and bromide) and $\mathrm{Fe}(\mathrm{II})$ in the supernatant were quantified by ion chromatography (Dionex DX-120 system fitted with an IonPac AS14 column and conductivity detector; Dionex, Sunnyvale, CA) and ferrozine assay (Stookey, 1970), respectively. Iron mound porewater sulfate and iron concentrations were calculated based on water content of a given volume of agarose plug. We were unable to detect bromide in the passive sampler plugs, indicating complete equilibration of the plug-associated fluid with surrounding iron mound porewater. Solid associated $\mathrm{Fe}(\mathrm{II})$ in iron mound sediments was quantified by extracting $\mathrm{Fe}(\mathrm{II})$ from iron mound material using 0.5 M HCl (Lovley and Phillips, 1987), followed by centrifugation to remove solids, and $\mathrm{Fe}(\mathrm{II})$ in the supernatant was quantified by ferrozine assay (Stookey, 1970). Total organic $\mathrm{C}$ and total $\mathrm{N}$ associated with iron mound sediments were quantified using a PerkinElmer 2400 Series II CHNS/O Analyzer (PerkinElmer Inc.; Waltham, MA). The mineralogy of Fe(III) phases in the iron mound was determined by X-ray powder diffractometry (XRD) using a Phillips 3100 automated diffractometer using $\mathrm{CuK} \alpha$ radiation, scanning at $2 \Theta$ of $2-70^{\circ}$, and accelerating voltage of $40 \mathrm{kV}$ at $35 \mathrm{~mA}$. Measurements of $\mathrm{x}$-ray intensities were determined with $0.02^{\circ}$ step size and $1 \mathrm{~s}$ counting time/step. Microprofiling of $\mathrm{pH}$ and DO were conducted using a Unisense (Unisense A/S, Aarhus, Denmark) microsensor system fitted with OX-N and PH-N DO and $\mathrm{pH}$ electrodes, respectively. Microprofiling of $\mathrm{pH}$ was conducted in the field, but since a DO electrode malfunctioned in the field, a core was obtained, returned to the laboratory, and DO microprofiling was subsequently conducted approximately $1.5 \mathrm{~h}$ after core collection. 


\section{MICROBIAL ENUMERATIONS}

To enumerate FeOB, a subsample of extruded core material (approximately $0.3 \mathrm{~g}$ ) was suspended in a solution containing

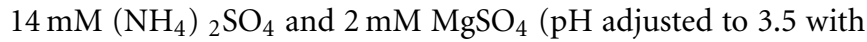
$\mathrm{H}_{2} \mathrm{SO}_{4}$ ), serially diluted in the same solution, and spread on solid medium-containing plates. The medium used for $\mathrm{FeOB}$ enumerations was based on that described by Johnson (1995), and contained $25 \mathrm{mM} \mathrm{FeSO}_{4}, 14 \mathrm{mM}\left(\mathrm{NH}_{4}\right)_{2} \mathrm{SO}_{4}, 2 \mathrm{mM} \mathrm{MgSO}_{4}$, $0.25 \mathrm{~g} / \mathrm{l}$ trypticase soy broth, vitamins and trace metals (Tanner, 1997). The $\mathrm{pH}$ of the medium was adjusted to 3.5 with $\mathrm{H}_{2} \mathrm{SO}_{4}$, and solidified with agarose $(20 \mathrm{~g} / \mathrm{l})$. Plates were incubated at room temperature in darkness, and FeOB colony forming units (CFU) were counted based on the formation of rust-colored colonies.

To enumerate $\mathrm{Fe}(\mathrm{III})$ reducing bacteria (FeRB), a subsample of the extruded core material (approximately $0.3 \mathrm{~g}$ ) was transferred to an anoxic glovebag (Coy Laboratory Products, Grass Lake, MI). Sediment was suspended in an acidophilic, anaerobic FeRB medium described by Senko et al. (2009) that contained $25 \mathrm{mM}$ $\mathrm{Fe}_{2}\left(\mathrm{SO}_{4}\right)_{3}, 10 \mathrm{mM}\left(\mathrm{NH}_{4}\right)_{2} \mathrm{SO}_{4}, 2 \mathrm{mM} \mathrm{MgSO} 4,5 \mathrm{mM}$ glucose, $0.5 \mathrm{~g} / \mathrm{l}$ trypticase soy broth, vitamins and trace metals (Tanner, 1997). The $\mathrm{pH}$ of the medium was adjusted to 4.2 with $\mathrm{NaOH}$, which caused the formation of $\mathrm{Fe}$ (III) (hydr)oxide precipitate in the medium. After preparation of the initial suspension of iron mound sediment in the FeRB medium, the suspension was serially diluted in a three-tube most probable number (MPN) series (Colwell, 1979) and incubated at room temperature in the dark. MPN series were scored based on the accumulation of $\geq 4 \mathrm{mM}$ $\mathrm{Fe}(\mathrm{II})$ in the medium.

To enumerate total bacterial abundances present in the MF iron mound sediments, $\mathrm{Fe}$ (III) (hydr)oxides were first removed by washing with $0.3 \mathrm{M}$ ammonium oxalate ( $\mathrm{pH}$ adjusted to 3.0 with oxalic acid; Nicomrat et al., 2006; Senko et al., 2008). After ammonium oxalate washing, cell pellets were resuspended in phosphate-buffered saline solution, immobilized on a Isopore membrane filter $(0.4 \mu \mathrm{m}$ pore size; Millipore, Billerica, MA), attached to microscope slides, and stained with $4^{\prime}, 6$-diamidino$2^{\prime}$-phenylindole (DAPI). Cells were visualized using an Olympus BX53 fluorescent microscope (Olympus America, Inc.; Center Valley, PA). Cell abundances were determined based on the average of 100 fields of view. To evaluate the possibility that the ammonium oxalate-washing step could damage cells and confound DAPI-based enumerations, cells from a late log phase culture of Shewanella oneidensis MR-1 were subjected to the ammonium oxalate washing procedure described above. Similar abundances of cells were observed in the DAPI-stained, ammonium oxalate cell suspension as in a DAPI-stained, unwashed cell suspension, indicating that the ammonium oxalate-washing step did not interfere with visualization of DAPI-stained cells.

\section{NUCLEIC ACID-BASED MICROBIAL COMMUNITY CHARACTERIZATION}

In preparation for nucleic acid-based microbial community analysis, cores were removed from the $-80^{\circ} \mathrm{C}$ freezer, and a small rotating saw was used to cut the core barrel length-wise. The halves of the core barrel were separated, and since the frozen sediments adhered to the core barrel, the interior of the sediment core was exposed. Samples were collected at $1 \mathrm{~cm}$ intervals from the interior of the core using sterile spatulas, and Fe(III) from the iron mound sediments was removed using $0.3 \mathrm{M}$ ammonium oxalate as described above. Genomic DNA was extracted from the remaining material using MoBio (MoBio Laboratories, Inc., Carlesbad, CA) PowerBiofilm DNA isolation kits according to the manufacturer's instructions. Partial 16S rRNA gene sequences were obtained using tag-encoded FLX amplicon pyrosequences at Molecular Research LP (Shallowater, TX). The 16S universal primers based on Escherichia coli 16S rRNA gene positions 515 and 806 were used for a single-step 30 cycle PCR using HotStarTaq Plus Master Mix Kit (Qiagen, Valencia, CA) under the following conditions: $94^{\circ} \mathrm{C}$ for $3 \mathrm{~min}$, followed by 28 cycles of $94^{\circ} \mathrm{C}$ for $30 \mathrm{~s}$, and $53^{\circ} \mathrm{C}$ for $40 \mathrm{~s}$ and $72^{\circ} \mathrm{C}$ for $1 \mathrm{~min}$, followed by a final 5 min elongation step at $72^{\circ} \mathrm{C}$. All PCR amplicon products were mixed in equal concentrations and purified using Agencourt Ampure beads (Agencourt Bioscience Corporation, MA, USA). Samples were sequenced following the manufacturer's instructions using Roche (Roche Diagnostics Corp., Indianapolis, IN) 454 FLX titanium instruments and reagents. Upon obtaining sequence data, barcodes and primers were removed from sequences, and chimeras, sequences of $<200 \mathrm{bp}$, sequences with ambiguous base calls, and/or sequences with homopolymer runs of $>6 \mathrm{bp}$ were removed from libraries (Gontcharova et al., 2010). Nucleotide sequence libraries from each depth have been submitted to the Sequence Read Archive (SRA) under run accession numbers SRR1206276 (0-1 cm depth interval), SRR1206277 (1-2 cm depth interval), SRR1206278 (2-3 cm depth interval), SRR1206279 (3-4 cm depth interval), SRR1206280 (4-5 cm depth interval), SRR1206281 (5$6 \mathrm{~cm}$ depth interval), SRR1206282 (6-7 cm depth interval), SRR1206283 (7-8 cm depth interval), SRR1206284 $(8-9 \mathrm{~cm}$ depth interval), SRR1206285 (9-10 cm depth interval).

Standard rarefaction curves (based on $97 \%$ sequence similarity), Shannon, and Chaol diversity indices were developed for sequence libraries from each depth interval using the Ribosomal Database Project-II (RDP-II) Pyrosequencing Pipeline (Cole et al., 2009). Further sequence processing was performed using the QIIME software package (Caporaso et al., 2011) in the MacQIIME environment (http://www.wernerlab.org/software/ macqiime) using default parameters. Operational taxonomic units $\left(\mathrm{OTU}_{0.03}\right)$ were determined at $97 \%$ sequence identity and picked using QIIME scripts (Edgar, 2010). Taxonomic assignments were subsequently made to OTU $\mathrm{O}_{0.03}$ using the RDP-II classifier function while still in the QIIME environment (Wang et al., 2007). OTU $U_{0.03}$ comprising $\geq 0.5 \%$ of sequences in libraries from each depth interval were identified and compared to sequences contained in the National Center for Biotechnology Information (NCBI) database using the Basic Local Alignment Search Tool (BLASTn; Altschul et al., 1997). The PyNAST algorithm was used to align sequences against the Greegenes core sequence set (DeSantis et al., 2006), and a phylogenetic tree containing $\mathrm{OTU}_{0.03}$ from all depth intervals was constructed in QIIME. The $\mathrm{OTU}_{0.03}$ table from each sample was interatively rarified using jack-knife sampling to 7844 sequences, and distance matrices were developed using the weighted and unweighted UniFrac metrics (Lozupone et al., 2007). Clustering of microbial communities associated with different depth intervals was evaluated by construction of unweighted pair group method with arithmetic 
mean (UPGMA) trees based on distance matrices produced using UniFrac (Lozupone et al., 2007).

\section{RESULTS AND DISCUSSION GEOCHEMICAL AND MINERALOGICAL GRADIENTS IN MF IRON MOUND SEDIMENTS}

The dissolved $\mathrm{Fe}$ (II) concentration at the $0-0.5 \mathrm{~cm}$ depth interval was lower than that of the overlying fluid and $\mathrm{pH}$ was lowest at the sediment-water interface, indicating oxidative precipitation of $\mathrm{Fe}(\mathrm{II})$ (Equation 1) in this region of the iron mound sediments (Figures 1A,B).

$$
4 \mathrm{Fe}^{2+}+\mathrm{O}_{2}+10 \mathrm{H}_{2} \mathrm{O} \rightarrow 4 \mathrm{Fe}(\mathrm{OH})_{3}+8 \mathrm{H}^{+}
$$

Dissolved Fe(II) increased with depth concomitantly with depletion of $\mathrm{O}_{2}$, reaching a maximum $\mathrm{Fe}(\mathrm{II})$ concentration of $15 \mathrm{mM}$ approximately $2.5 \mathrm{~cm}$ below the sediment water interface (Figures 1A,B). The maximum aqueous $\mathrm{Fe}$ (II) concentration within the iron mound sediments exceeds that of the overlying AMD (Figure 1A), indicating that reductive dissolution of iron mound $\mathrm{Fe}$ (III) phases is occurring in this depth interval. With increasing depth below approximately $2.5 \mathrm{~cm}$, the $\mathrm{Fe}(\mathrm{II})$ concentration decreased (Figure 1A). Fe(II) adsorbs strongly to $\mathrm{Fe}(\mathrm{III})$ (hydr)oxide phases (e.g., Jeon et al., 2003; Jang et al., 2008), so the MF iron mound sediments themselves represent a potential pool of $\mathrm{Fe}(\mathrm{II})$. Indeed, we detected a large fraction of solid associated (0.5 M HCl-extractable) Fe(II) adsorbed to sediments in the upper $2 \mathrm{~cm}$ of the iron mound (Figure 1A). However, the solid associated Fe(II) content of sediments diminished with depth (Figure 1A), indicating that decrease in aqueous $\mathrm{Fe}$ (II) concentration below $2.5 \mathrm{~cm}$ may not be exclusively due to adsorption of $\mathrm{Fe}$ (II) on $\mathrm{Fe}$ (III) (hydr)oxide phases in the iron mound sediment. Porewater sulfate concentration was lower than the overlying AMD, and decreased slightly in the depth interval between the sediment-water interface and approximately $2 \mathrm{~cm}$, but changed little below this depth (Figure 1C). Since sulfate depletion occurred in a depth interval that contained abundant dissolved oxygen (Figure 1C), it is unlikely attributable to sulfate reduction. Rather, the removal of sulfate from solution could be attributable to adsorption of sulfate on freshly precipitated Fe(III) phases (Parfitt and Smart, 1977) or incorporation into $\mathrm{Fe}$ (III) (hydr)oxysulfates such as schwertmannite (Bigham et al., 1990; Burton et al., 2007), concurrently with Fe(II) oxidation near the sediment-water interface. TOC and total $\mathrm{N}$ were highest in the shallowest portion of the iron mound (Figure 1D), suggesting primary productivity in this region of the iron mound. With increasing depth within the iron mound, both TOC and total N were depleted (Figure 1B).

Geochemical evaluations of the MF iron mound indicated that aerobic microbial activities were occurring most extensively in the upper $2.5 \mathrm{~cm}$ of the sediments, but $\mathrm{Fe}(\mathrm{III})$ reduction was also occurring in this region, despite the presence of dissolved $\mathrm{O}_{2}$ to a depth of approximately $3 \mathrm{~cm}$ (Figures 1A,B). XRD patterns obtained from sediments in the $0-2 \mathrm{~cm}$ depth

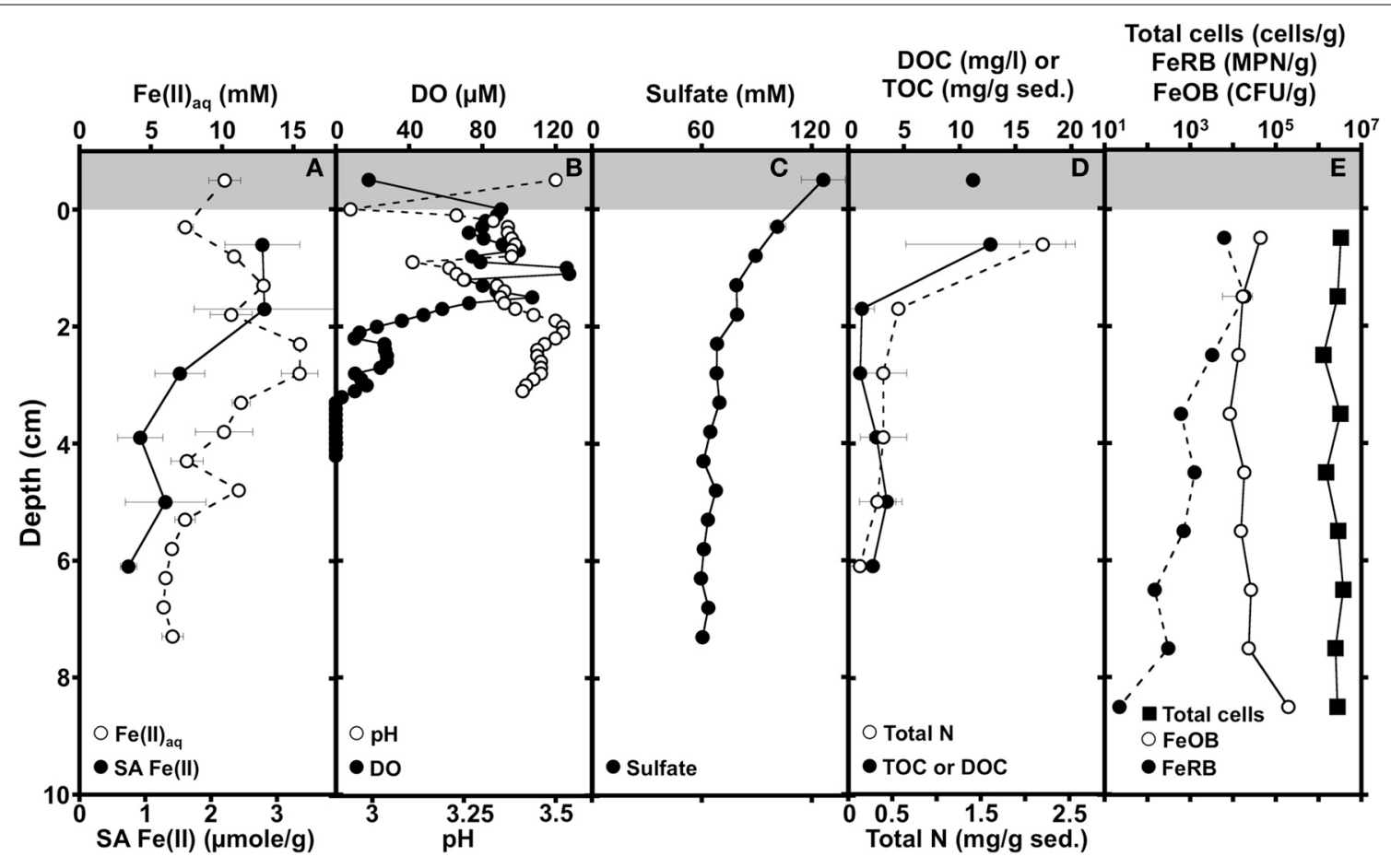

FIGURE 1 | Depth-dependent profiles of dissolved (Fe(II) aq) and solid-associated Fe(II) (0.5 M HCl-extractable; SA Fe(II)) (A), dissolved oxygen (DO) and pH (B), sulfate (C), Dissolved organic carbon (DOC) of overlying AMD, total organic carbon (TOC), and total nitrogen of sediments (D), and abundances of total cells, culturable $\mathrm{Fe}$ (II) oxidizing bacteria (FeOB), and culturable $\mathrm{Fe}(\mathrm{III})$ reducing bacteria (FeRB) in iron mound sediments (E). Shading at the top of the panels illustrates AMD overlying the sediments. Error bars represent one standard deviation. 


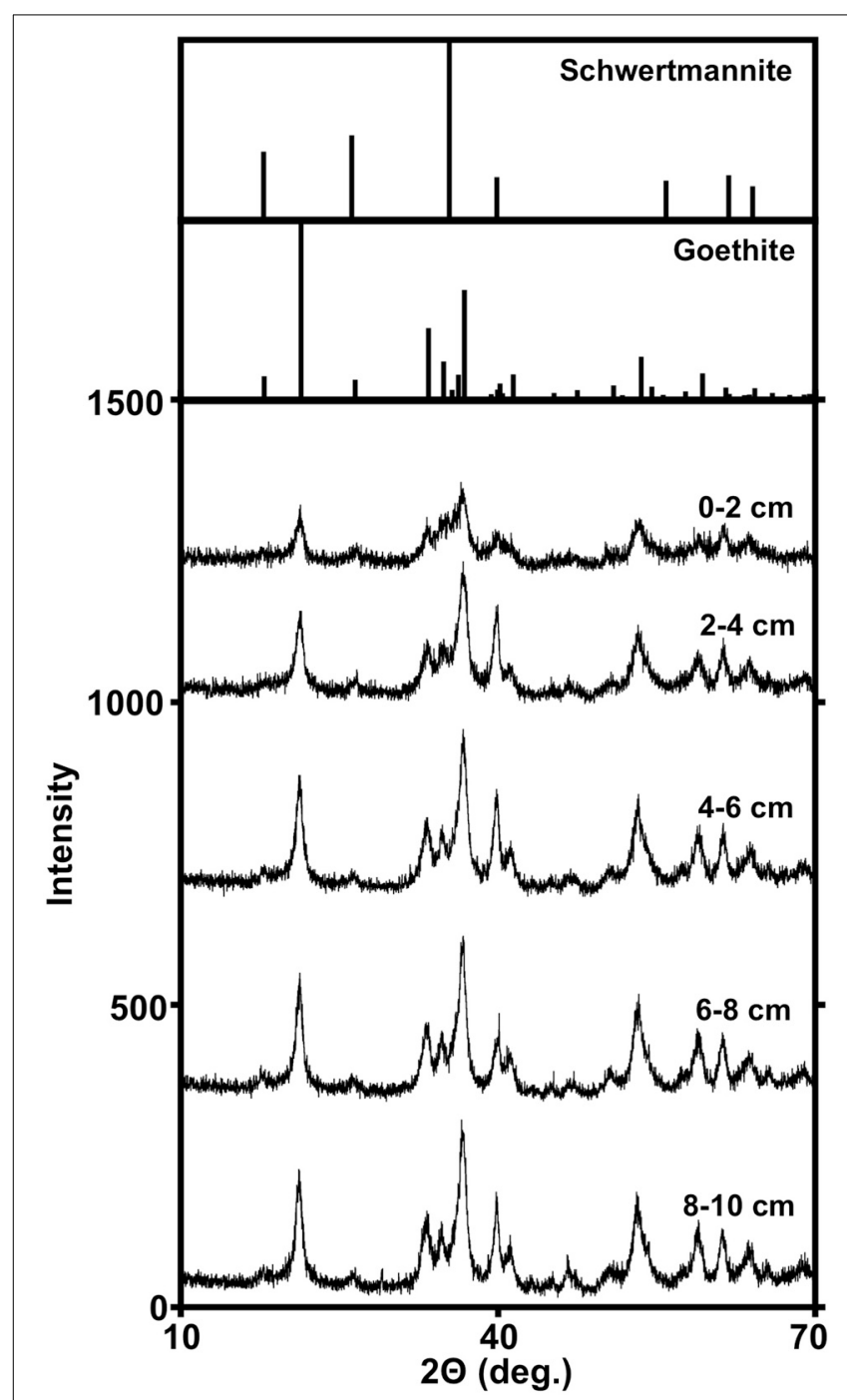

FIGURE 2 | Powder X-ray diffraction patterns of Fe(III)-rich phases recovered from different depths within the MF iron mound. Reference diffraction patterns of schwertmannite and goethite are from The American Mineralogist Crystal Structure Database (Downs and Hall-Wallace, 2003).

interval contained broad poorly resolved peaks indicative of goethite $(\alpha-\mathrm{FeOOH})$ of small grain size or poorly-crystalline $\mathrm{Fe}(\mathrm{III})$ phases, such as hydrous ferric oxide or schwertmannite $\left(\mathrm{Fe}_{8} \mathrm{O}_{8}(\mathrm{OH})_{6}\left(\mathrm{SO}_{4}\right) \bullet n \mathrm{H}_{2} \mathrm{O}\right)$, which is frequently observed as the predominant $\mathrm{Fe}$ (III) phase formed by biological or abiotic oxidation of $\mathrm{Fe}(\mathrm{II})$ in $\mathrm{AMD}$ with $\mathrm{pH}$ from 2.8 to 4.5 (Figure 2; Bigham et al., 1996a,b; Burgos et al., 2012). With increasing depth in the iron mound, we observed higher peak to background ratios and XRD patterns indicating goethite (Figure 2). This depth-dependent development of goethite from poorly crystalline phases is typical of AMD-derived Fe(III) (hydr)oxide sediments and non-acidic systems, and may be induced by Fe(III)- and/or sulfate-reducing bacterial activities (Hansel et al., 2003; Burton et al., 2007; Bertel et al., 2012). While no iron sulfide phases were detected by XRD, biogenic sulfide reacts rapidly with $\mathrm{Fe}$ (III) phases in such systems (Neal et al., 2001; Poulton et al., 2004).
As such, any sulfide produced by sulfate reducing bacterial activities would be unlikely to accumulate, but would be oxidized by $\mathrm{Fe}$ (III) to a variety of partially oxidized S species (Neal et al., 2001; Poulton et al., 2004).

\section{CULTURE-DEPENDENT CHARACTERIZATION OF MICROBIAL COMMUNITIES ASSOCIATED WITH MF IRON MOUND SEDIMENTS}

Both geochemical and mineralogical evaluations of the MF iron mound suggested concomitant aerobic and anaerobic activities in the upper $\sim 3 \mathrm{~cm}$ of the iron mound sediments, though indications of anaerobic activity [i.e., Fe(II) accumulation or sulfate depletion] below this depth could not be detected. As such, we sought to evaluate the microbial communities associated with the iron mound at discrete depth intervals. Total abundances of microbial cells were uniform throughout the column (Figure 1E). Similarly, culturable aerobic Fe(II) oxidizing bacterial (FeOB) abundances were similar throughout the iron mound sediments, though they were most abundant in the $0-1 \mathrm{~cm}$ interval and 9-10 cm interval (Figure 1E). Culturable Fe(III) reducing bacterial (FeRB) abundances increased slightly from the $0-1 \mathrm{~cm}$ depth interval to the $1-2 \mathrm{~cm}$ depth interval [where dissolved $\mathrm{Fe}$ (II) concentrations indicated $\mathrm{Fe}$ (III) reduction was occurring], and subsequently decreased in abundance with increasing depth in the iron mound (Figure 1E). The relatively uniform abundances of aerobic FeOB and depth-dependent decrease in FeRB abundances was somewhat surprising, since dissolved $\mathrm{O}_{2}$ was depleted below approximately $3 \mathrm{~cm}$ in the iron mound sediments. While the abundance of culturable FeOB has been illustrated to be an indicator of rates of $\mathrm{Fe}(\mathrm{II})$ oxidation in iron mound sediments (Senko et al., 2011), the uniform distribution of FeOB and diminished abundance of FeRB with depth in the MF iron mound sediments may be a reflection of the metabolic versatility of Fe metabolizing acidophilic microorganisms. For instance, several organisms classified as aerobic FeOB may also respire $\mathrm{Fe}(\mathrm{III})$ or partially reduced $\mathrm{S}$ species under anoxic conditions (Johnson and McGinness, 1991; Pronk et al., 1992; Küsel et al., 1999; Hedrich et al., 2011), so the aerobic FeOB that were detected may have been metabolizing anaerobically in $\mathrm{O}_{2}$-depleted regions of the iron mound. Similarly, no obligately anaerobic acidophilic FeRB have been recovered in culture. While acidophilic/acidtolerant SRB capable of Fe(III) reduction have been isolated from AMD-impacted systems, it remains unclear whether these organisms can couple Fe(III) reduction to growth (Senko et al., 2009; Alazard et al., 2010). Several aerobic organotrophic acidophilic microorganisms capable of $\mathrm{Fe}(\mathrm{III})$ respiration have been isolated (Johnson and McGinness, 1991; Pronk et al., 1992; Küsel et al., 1999; Hedrich et al., 2011). As such, the greater abundance of culturable FeRB that we detected in shallower regions of the MF iron mound may be a reflection of the increased availability of organic carbon in these portions of the sediment (Figure 1D), since we enumerated FeRB using glucose as an electron donor. Alternatively, the higher numbers of FeRB in the shallower sediments may be attributable to the abundance of poorly crystalline $\mathrm{Fe}$ (III) phases, which may be more susceptible to bioreduction than goethite (Burton et al., 2007). The recovered FeOB and FeRB comprised $\leq 1 \%$ of total cells detected by microscopic counting of DAPI-stained cells, and similarly poor recoveries of cells in 
culture have been reported from other AMD-impacted systems (Hallberg et al., 2006). Despite the relatively poor recovery of Fe metabolizing organisms, it remains notable that FeOB and FeRB were in close spatial association with each other within the iron mound sediments.

\section{NUCLEIC ACID-BASED CHARACTERIZATION OF MICROBIAL COMMUNITIES ASSOCIATED WITH MF IRON MOUND SEDIMENTS}

We used "next generation" DNA sequencing to evaluate partial (average read length 264 bp) 16S rRNA gene sequences from microorganisms associated with MF iron mound sediments at $1 \mathrm{~cm}$ depth intervals. The number of sequences recovered from each depth interval ranged from 7844 to 18,385 (Table 1). Non-parametric indicators of community diversity (Chaol and Shannon indices) revealed that the diversity of the communities was uniformly low throughout the sediments (Table 1), in comparison to nearby AMD-unimpacted soil (Brantner and Senko, unpublished). UPGMA clustering of microbial communities using the Unifrac metric for comparison of community composition (Lozupone et al., 2007) revealed depth-dependent segregation of microbial communities within the MF iron mound sediments (Figure 3). Microbial communities at depths below $4 \mathrm{~cm}$ clustered together regardless of whether the unweighted or weighted Unifrac metrics were used to compare the communities (Figure 3). While the microbial community from the $1-2 \mathrm{~cm}$ depth interval did not cluster with those associated with depths below $4 \mathrm{~cm}$, it also did not cluster with communities associated with the $0-1$ and $2-4 \mathrm{~cm}$ depth intervals (Figure 3), likely due to the high relative abundance of chloroplast-attributable $16 \mathrm{~S}$ rRNA gene sequences detected at this depth interval (discussed in more detail below). Clustering of microbial communities based on position above and below $4 \mathrm{~cm}$ depth indicated that the availability of $\mathrm{O}_{2}$ exerted some control on the composition of the microbial communities.

When viewed from the phylum level, Gammaproteobacterial phylotypes were abundant throughout the iron mound sediments, comprising approximately $20 \%$ or more of the sequences in libraries obtained from each depth interval, and comprised a slightly higher fraction of the microbial community at depths

Table 1 | Information on 16S rRNA gene sequence libraries and non-parametric diversity estimates of microbial communities from MF iron mound.

\begin{tabular}{lcccc}
\hline $\begin{array}{l}\text { Depth } \\
\text { interval }\end{array}$ & $\begin{array}{c}\text { Number of } \\
\text { sequences }\end{array}$ & $\begin{array}{c}\text { Number of } \\
\text { OTU }\end{array}$ & $\begin{array}{c}\text { Chao1 } \\
\text { index }\end{array}$ & $\begin{array}{c}\text { Shannon } \\
\text { index }\end{array}$ \\
\hline $0-1 \mathrm{~cm}$ & 18,385 & 668 & 994 & 4.44 \\
$1-2 \mathrm{~cm}$ & 14,350 & 457 & 737 & 4.02 \\
$2-3 \mathrm{~cm}$ & 10,718 & 522 & 824 & 4.35 \\
$3-4 \mathrm{~cm}$ & 8654 & 523 & 653 & 4.09 \\
$4-5 \mathrm{~cm}$ & 8529 & 423 & 491 & 3.99 \\
$5-6 \mathrm{~cm}$ & 15,694 & 673 & 968 & 4.49 \\
$6-7 \mathrm{~cm}$ & 13,553 & 652 & 866 & 4.53 \\
$7-8 \mathrm{~cm}$ & 8204 & 498 & 637 & 3.98 \\
$8-9 \mathrm{~cm}$ & 7844 & 366 & 418 & 3.91 \\
$9-10 \mathrm{~cm}$ & 17,645 & 637 & 936 & 4.33
\end{tabular}

below $4 \mathrm{~cm}$ (Figure 4). Betaproteobacteria- and Cyanobacteriaaffiliated phylotypes were prominent representatives of sequence libraries recovered from the upper $4 \mathrm{~cm}$ of the iron mound, but decreased in relative abundance below $4 \mathrm{~cm}$ (Figure 4). Unclassifiable Bacteria- and, to a lesser extent, Chloroflexi- and Euryarchaeota-affiliated phylotypes increased in relative abundance with depth in the iron mound sediments (Figure 4).

Phylotypes attributable to WPS-2, Firmicutes, AD3, Acidobacteria, and Actinobacteria each comprised 1-5\% of total sequences in the iron mound sediments, but clear depthdependent trends in their relative abundances were not observed (Figure 4). Anywhere from 19 to $26 \mathrm{OTU}_{0.03}$ represented $\geq 0.5 \%$ of sequences in libraries derived from each depth interval, and comprised $72-78 \%$ of the total sequences in each library (Figure 5). Of these $\mathrm{OTU}_{0.03}$, a set of nine OTU $\mathrm{O}_{0.03}$ attributable to Acidobacteria, Gammaproteobacteria, Betaproteobacteria, Chloroflexi, AD3, and unclassifiable Bacteria were detected throughout the iron mound sediments at abundances $\geq 0.5 \%$ of respective sequence libraries (Figure 5). To make more specific taxonomic assignments to these numerically prominent phylotypes, we compared OTU $\mathrm{U}_{0.03}$ represented in Figure 5 to sequences contained in the GenBank database using BLASTn (Altschul et al., 1997; Table 2). The majority of these OTU $\mathrm{O}_{0.03}$, particularly those detected in the upper portion of the iron mound, as well as those assignable to the most abundant phyla (i.e., Gamma- and Betaproteobacteria, Cyanobacteria, and unclassifiable Bacteria), were $96-100 \%$ similar to $16 \mathrm{~S}$ rRNA gene sequences detected in AMD-impacted systems (Figure 5, Table 2).

The abundant Gammaproteobacterial $\mathrm{OTU}_{0.03}$ were related to phylotypes detected in AMD-impacted systems and were

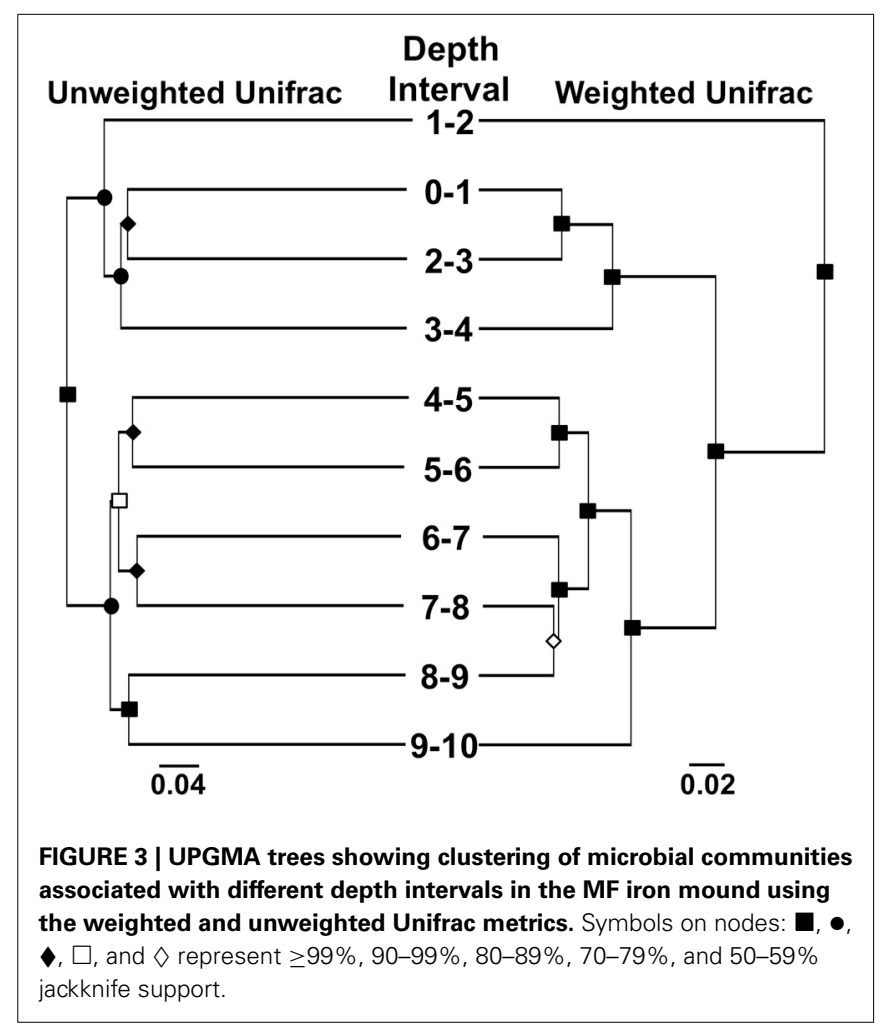




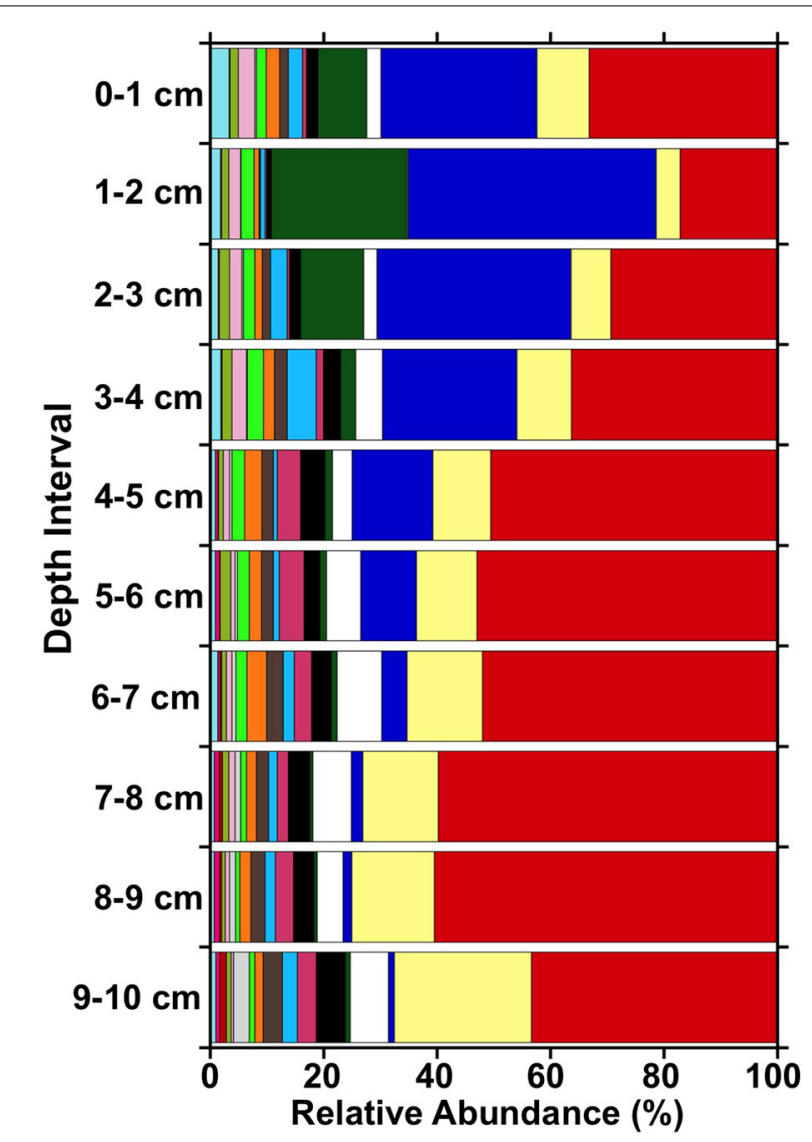

\begin{tabular}{|c|c|}
\hline Gammaproteobacteria & Acidobacteria \\
\hline Unclassified Bacteria & Actinobacteria \\
\hline Betaproteobacteria & Deltaproteobacteria \\
\hline Chloroflexi & Alphaproteobacteria \\
\hline Cyanobacteria & Unclassified Proteobacteria \\
\hline WPS-2 & Chrenarchaeota \\
\hline Euryarchaeota & Nitrospirae \\
\hline Firmicutes & Other Bacteria \\
\hline
\end{tabular}

FIGURE 4 | Relative abundances of 16S rRNA gene sequences detected in libraries from different depths within the MF iron mound at phylum-level and class-level (in the cases of the Proteobacteria) taxonomic resolution.

affiliated with the order Xanthomonadales, using the RDP-II classifier function (Figure 5, Table 2), which have been previously detected in iron mound systems (Senko et al., 2008). The most abundant phylotype detected in the MF iron mound, regardless of depth, was 98-99\% similar to acidophilic Metallibacterium sp. $\mathrm{X} 11$ and $M$. scheffleri (Figure 5, Table 2). These organisms, and the closely related strains A4F5, WJ2, and YE3-D1-10-CH, represent a metabolically versatile group of acidophilic, heterotrophic organisms, capable of aerobic organotrophic and lithotrophic (using Fe(II) and reduced sulfur species) metabolism, as well as anaerobic Fe(III) respiration (Coupland and Johnson, 2008; Lu et al., 2010; Delavat et al., 2012; Wu et al., 2013; Ziegler et al.,
2013). This metabolic versatility [most notably the ability to oxidize $\mathrm{Fe}(\mathrm{II})$ and reduce $\mathrm{Fe}(\mathrm{III})$ ] may explain the relatively uniform distribution of these phylotypes within the MF iron mound, and the apparent sustained microbial metabolism (as indicated by cell abundances; Figure 1E), regardless of the prevailing geochemical conditions. This may also explain the relatively high abundance of culturable organotrophic FeRB in regions of the iron mound that contained high DO concentrations (Figure 1).

The abundance of Cyanobacteria-affiliated phylotypes in the top $3 \mathrm{~cm}$ of the MF iron mound was initially surprising (Figure 4), since cyanobacteria are not frequently encountered in AMD-impacted settings (González-Toril et al., 2003), but more detailed examination of these sequences revealed that they were attributable to chloroplast $16 \mathrm{~S}$ rRNA gene sequences of phototrophic microeukaryotes (Figure 5, Table 2). A variety of phototrophic microeukaryotes may be present in AMD-impacted setting (Rowe et al., 2007; Sánchez España et al., 2007; Senko et al., 2011), including Euglena mutabilis (Brake et al., 2004; Aguilera et al., 2007; Brake and Hasiotis, 2010), which was the most abundant phototrophic microeukaryotic phylotype detected in the sediments (Figure 5, Table 2). Notably, the abundance of phototrophic microeukaryotic phylotypes was coincident with relatively high DO concentration (Figures 1, 4). While it is unclear whether these organisms were active below the sediment water interface, it appears that their activities contributed to the relatively high TOC of the shallower regions of the iron mound (Figure 1D). It is not clear how light is attenuated within iron mound sediments, so we cannot determine whether the phototrophic microeukaryotes detected in deeper sediments were active, or if the DNA recovered was a remnant of organisms that were previously active near the sediment-AMD interface and were simply buried, now-inactive cells. Below $2 \mathrm{~cm}$ the relative abundances of phototrophic microeukaryotic phylotypes diminished dramatically (Figure 4), concurrently with the diminished abundance of TOC (Figure 1D), indicating that after burial in Fe(III) (hydr)oxides, the activities of these organisms were diminished and the organic carbon that they produced was degraded.

The most abundant Betaproteobacteria-affiliated $\mathrm{OTU}_{0.03}$ were taxonomically assigned by the RDP-II classifier function as Gallionella spp., which are neutrophilic, aerobic FeOB (Emerson et al., 2010). However, analysis of these OTU $\mathrm{O}_{0.03}$ using BLASTn revealed that they were attributable to $\mathrm{Fe}(\mathrm{II})$ oxidizing "Ferrovum" spp. and Leptothrix ocracea (Figure 5, Table 2). "Ferrovum" spp. are aerobic, acidophilic, and autotrophic FeOB (Hedrich et al., 2009; Heinzel et al., 2009; Tischler et al., 2013) that have been illustrated to be the predominant organisms present in AMD-impacted systems exhibiting similar physicochemical characteristics to the MF iron mound (Hallberg et al., 2006; Brown et al., 2011). L. ocracea is a neutrophilic FeOB (Fleming et al., 2011), though phylotypes similar to the one recovered from the MF iron mound have been observed in AMD-impacted systems, suggesting that the phylotypes detected here may be acidophilic lineages of Leptothrix.

While Chloroflexi-affiliated and unassignable Bacterial phylotypes were relatively abundant in libraries from each depth interval, they increased in relative abundance in the deeper regions of the iron mound (Figure 4). Robust taxonomic assignments 


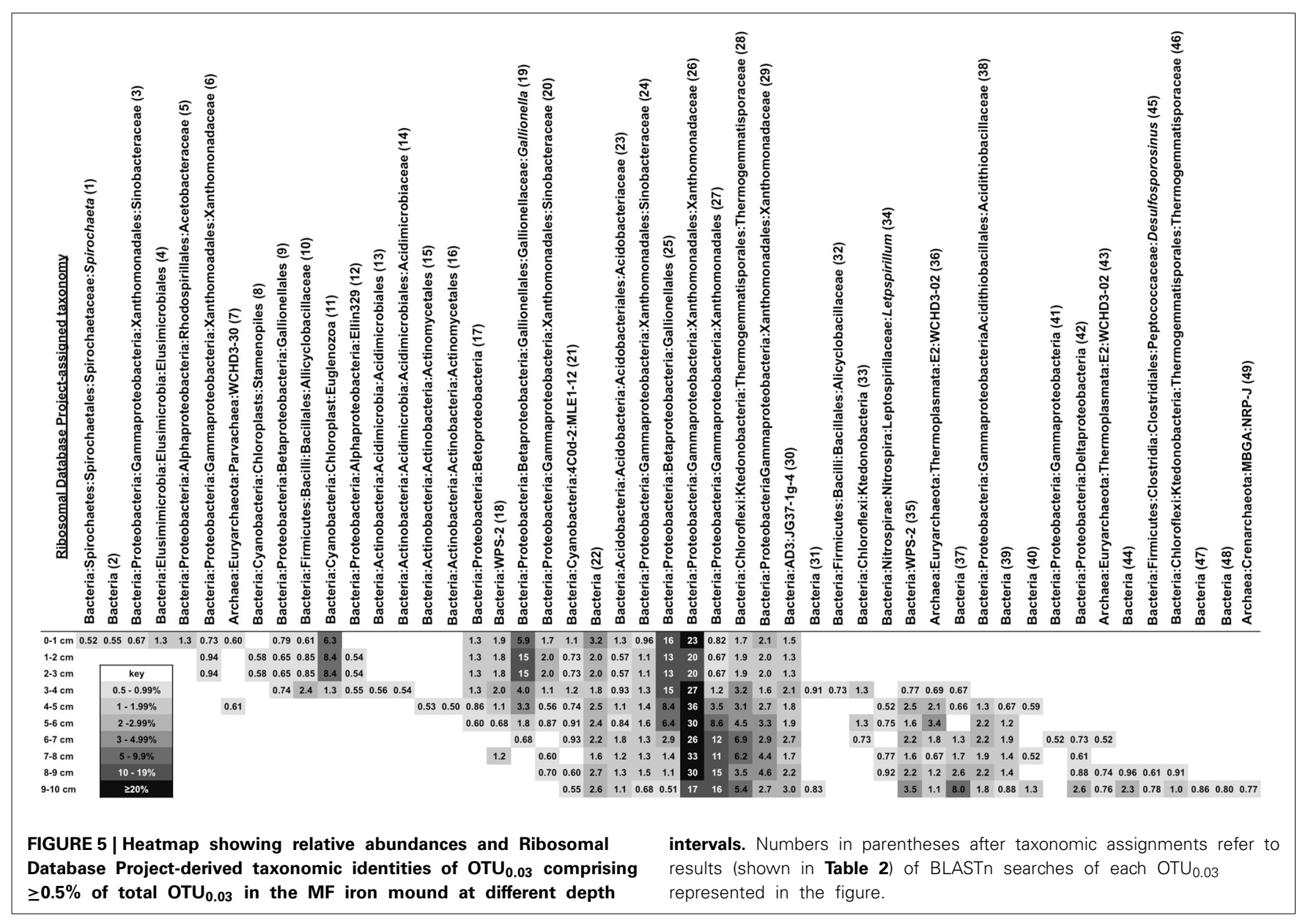

could not be made to the most abundant Chloroflexi-affiliated phylotypes, but phylotypes affiliated with this phylum have been detected in other AMD-impacted systems, including a physicochemically similar iron mound (Senko et al., 2008; Lucheta et al., 2013). The role of Chloroflexi in AMD-impacted systems remain unclear, but their slightly increased relative abundance in deeper portions of the iron mound suggests that they may be capable of anaerobic metabolism. Several of the unassignable Bacteriaaffiliated phylotypes were $97-99 \%$ similar to sequences associated with AMD-impacted systems (Figure 5, Table 2). The prominent representation of unassignable Bacteria-affiliated sequences in libraries recovered from the deeper, anoxic portions of the iron mound suggests a large uncharacterized pool of microorganisms in anoxic portions of AMD-impacted systems in comparison to relatively well characterized near-surface portions (e.g., Senko et al., 2008; Amaral-Zettler et al., 2011; Brown et al., 2011).

Despite the high relative abundance of Gammaproteobacteriaaffiliated phylotypes throughout the MF iron mound, phylotypes attributable to the well-characterized genus of acidophilic $\mathrm{FeOB}$ Acidithiobacillus did not comprise a large fraction of Gammaproteobacterial sequences. However, phylotypes attributable to Acidithiobacillus spp. were detected at relative abundances of 1.3-2.2\% in sediments below $4 \mathrm{~cm}$ (Figure 5, Table 2). Acidithiobacillus spp. are facultatively anaerobic, capable of coupling oxidation of $\mathrm{H}_{2}$ or reduced sulfur species to the reduction of $\mathrm{Fe}$ (III) (Hedrich et al., 2011), so the higher relative abundances of Acidithiobacillus-phylotypes in deeper portions of the iron mound may be a reflection of their ability to metabolize under $\mathrm{O}_{2}$-limited conditions. Similarly, Euryarchaeotaand Nitrospirae-affiliated phyltypes attributable to the class Thermoplasmata and genus Leptospirillum, respectively, were most abundant in sequence libraries derived from sediments below $4 \mathrm{~cm}$ (Figures 4,5). Thermoplasmata include the extremely acidophilic (optimal $\mathrm{pH}$ approximately 1.5), obligately aerobic autotrophic $\mathrm{Fe}(\mathrm{II})$ oxidizing Ferroplasma spp. (Edwards et al., 2000; Golyshina et al., 2000 science), though RDP-II-assigned taxonomy indicated that the abundant Euryarchaeal phylotypes (Figure 5) were similar to those detected in methanogenic marine sediments, suggesting the possibility of methanogenesis in anoxic regions of the iron mound sediments. Leptospirillum spp. are also aerobic autotrophic $\mathrm{FeOB}$ that are generally encountered in systems with $\mathrm{pH}<3$ (Hallberg and Johnson, 2003; Tyson et al., 2005). The detection of these phylotypes in the anoxic regions of the iron mound (Figure 1B) is surprising, particularly the phylotypes attributable to Leptospirillum spp., which are obligately aerobic (Fujimura et al., 2012).

No clear patterns in the relative abundances of WPS-2-, AD3-, Acidobacteria, and Firmicutes-affiliated phylotypes in sequence 


\section{Table 2 | Most closely related (based on BLASTn-determined similarity) 16S rRNA gene sequences from environmental surveys and cultured microorganisms to $\mathrm{OTU}_{0.03}$ comprising $\geq 0.5 \%$ of sequences in libraries recovered from different depth in the MF iron mound.}

\section{OTU \# Nearest environmental 16S rRNA gene sequence}

1 AMD-impacted Río Tinto (99\%; FN867143; Amaral-Zettler et al. 2011)

2 AMD-impacted Río Tinto (98\%; FN863828; Amaral-Zettler et al., 2011)

3 "Iron snow" in acidic mine lake (99\%; HE604017; Lu et al., 2013) Abandoned Cu mine (99\%; JO217995; Falteisek and Cepička, 2012)

\section{"Iron snow" in acidic mine lake (99\%; HE604030; Lu et al., 2013)}

Abandoned Cu mine (99\%; JQ217802; Falteisek and Cepička, 2012)

AMD-impacted Río Tinto (96\%; FN866063; Amaral-Zettler et al., 2011) Arctic stream epilithon (97\% FJ849138; Larouche et al., 2012)

Abandoned Cu mine (99\%; JO217544; Falteisek and Cepička, 2012); AMD iron mound (99\%; HQ420151; Brown et al., 2011)

AMD-impacted sediment (99\%; EF409850; Yin et al., 2008) AMD-impacted Río Tinto (99\%; FN862195; Amaral-Zettler et al., 2011)

Metal sulfide mine AMD (99\%; GU979565; Hao et al., 2010)

AMD-impacted Río Tinto sediment (99\%; JF737887; García-Moyano et al., 2012)

Acidic mine lake (99\%; KC619609; Santofimia et al., 2013)

Acidic wetland soil (99\%; GQ203360; Kopecky et al., 2011)

Acidic mine lake sediments (99\%; FN870199; Lu et al., 2010)

AMD iron mound (97\%; HQ420151; Brown et al., 2011); AMD-impacted Río Tinto (97\%; FN867145; Amaral-Zettler et al., 2011)

$$
\text { "Iron snow" in acidic mine lake (99\%; HE604029; Lu et al., 2013) }
$$

Abandoned Cu mine (99\%; JO217975; Falteisek and Cepička, 2012)

AMD-impacted Río Tinto (99\%; FN860398; Amaral-Zettler et al., 2011)

Acidic hot spring (97\%; JF280561; Bohorquez et al., 2012)

AMD-impacted Río Tinto (99\%; FN866617; Amaral-Zettler et al., 2011)

Abandoned Cu mine (99\%; JO218102; Falteisek and Cepička, 2012)

AMD-impacted Río Tinto sediment (99\%, HQ730615;

Sánchez-Andrea et al., 2011)

Abandoned Cu mine (99\%; JQ217544.1; Falteisek and Cepička, 2012)

AMD biofilm (99\%; JX297618.1; Guo et al., 2013)

AMD-impacted Río Tinto (99\%; FN862147; Amaral-Zettler et al., 2011)

\section{Nearest cultured 16S rRNA gene sequence}

Spirochaeta aurantia from freshwater (94\%; AJ565432; Hahn et al., 2004)

None found

Steroidobacter denitrificans $\mathrm{FS}, \mathrm{NO}_{3}^{-}$reducer from anoxic sludge $194 \%$; NR_044309) (Fahrbach et al., 2008)

Halothiobacillus kellyi BII-1, thermophilic S oxidizer (84\%; NR_025030;

Sievert et al., 2000)

Acidophilic FeOB C4H7 (99\%; JX869450; Wu et al., 2013)

Metallibacterium X11 adidophilic $\mathrm{S}_{2} \mathrm{O}_{3}^{2-}$ oxidizer (95\%; HE858262;

Delavat et al., 2012)

None found

Elphidium aculeatum A75.46 chloroplast (85\%; HM213365; Pillet et al., 2011)

Ferrovum myxofaciens EHS8, acidophilic FeOB (97\%; KC155322; Hedrich et al., 2009); Ferrovum myxofaciens PSTR, acidophilic FeOB (97\%; EF133508; Hallberg et al., 2006)

Acidophilic FeOB/FeRB iFeo-D4-31-CH (94\%; FN870336; Lu et al., 2010) Euglena mutabilis SAG 1224-9b chloroplast (96\%; AY626044;

Milanowski et al., 2006)

Rhizobiales strain A48, neutrophilic FeRB (94\%; AB081581; Satoh et al., 2002)

Aciditerrimonas ferrireducens, thermoacidophilic FeRB (92\%; AB517669; Itoh et al., 2011)

Acidophilic heterotrophic FeOB Py-F3 (96\%; KC208497; Kay et al., 2013) Actinoallomurus sp. 645152, acidophilic organotroph (96\%; AB604840; Murmatsu et al., 2011)

Acidophilic FeOB A4F6 (93\%; JX869415; Wu et al., 2013)

Ferrovum myxofaciens EHS8, acidophilic FeOB (97\%; KC155322; Hedrich et al., 2009); Ferrovum myxofaciens PSTR, acidophilic FeOB (97\%; EF133508; Hallberg et al., 2006)

Arhodomonas sp. Seminole, aerobic halophile (84\%; JX099567; Dalvi et al., 2012)

Leptothrix ochracea SCGC AAA018-M4 FeOB (98\%; HQ290506;

Fleming et al., 2011)

Acidophilic FeOB A4F5 (98\%; JX869415; Wu et al., 2013)

Anaerobic bacterium BSV83 (86\%; AJ229227; Hengstmann et al., 1999) Lysobacter sp. AP7 (82\%; EU374884; Alonso-Gutiérrez et al., 2009)

Acidophilic, organotrophic Acidobacteriaceae $\mathrm{CH} 1$ from AMD (97\%; DQ355184; Diaby et al., 2007)

Acidophilic FeOB A4F5 (98\%; JX869414; Wu et al., 2013)

Ferrovum myxofaciens EHS8, acidophilic FeOB (99\%; KC155322; Hedrich et al., 2009); Ferrovum myxofaciens PSTR, acidophilic FeOB (99\%; EF133508; Hallberg et al., 2006)

Metallibacterium X11 adidophilic $\mathrm{S}_{2} \mathrm{O}_{3}^{2-}$ oxidizer (99\%; HE858262; Delavat et al., 2012); Metallibacterium scheffleri DKE6, acidophilic facultative FeRB (98\%; HO909259.1; Ziegler et al., 2013)

Thiohalophilus thiocyanatoxydans HRhD 2, halophilic S oxidizer (91\%; NR_043875; Sorokin et al., 2006) 


\section{Table 2 | Continued}

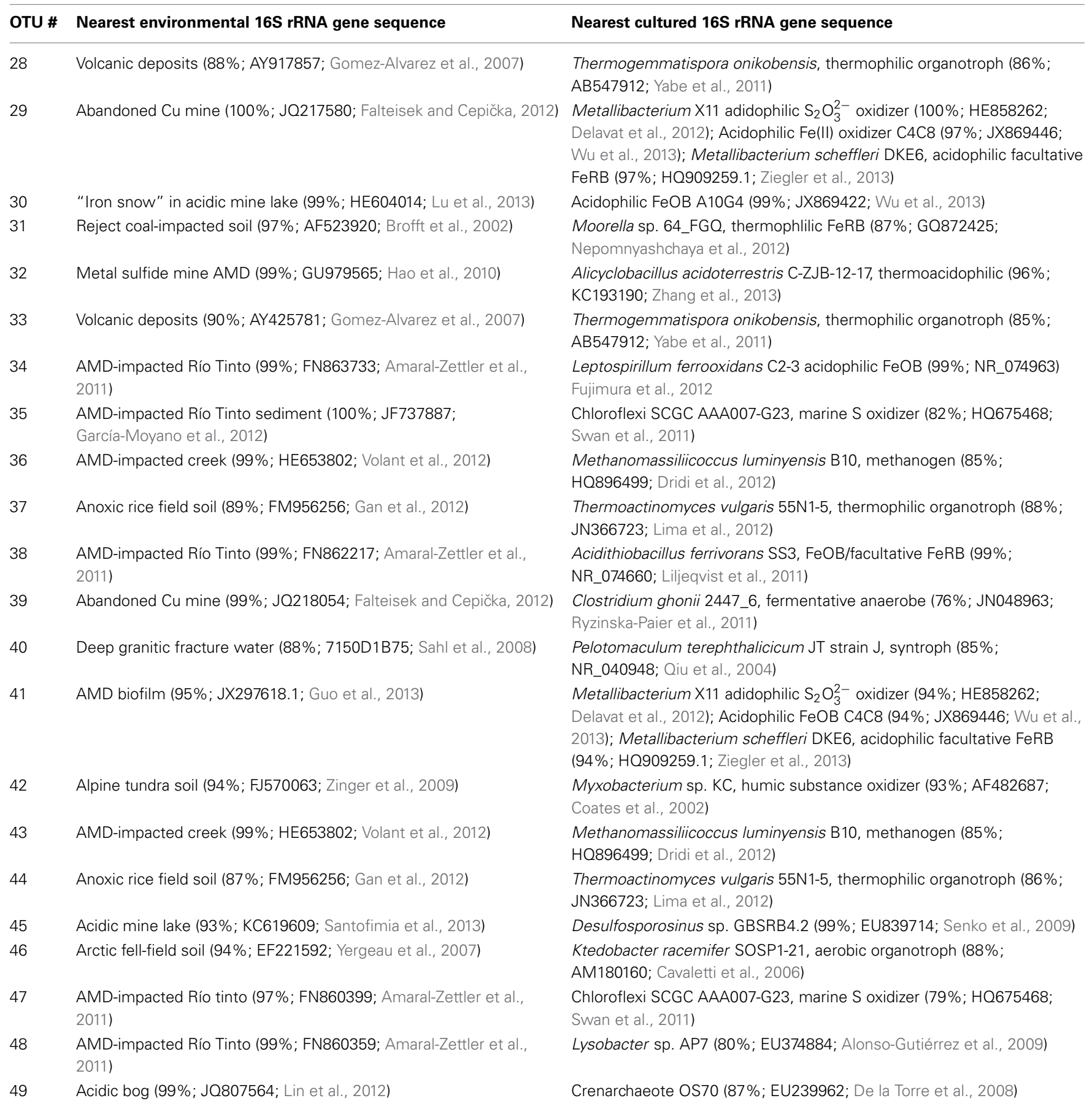

OTU numbers in the left hand column refer to OTU number designations in Figure 5. Percent similarities, GenBank accession numbers, and appropriate references of sequences are provided in parentheses.

libraries from various depths within the MF iron mound were observed, and representatives of these phyla comprised $1-5 \%$ of total sequences within the respective libraries (Figure 4). While the most abundant WPS-2-affiliated OTU $\mathrm{O}_{03}$ (Figure 5) were similar to phylotypes detected in AMD-impacted systems, they could not be reliably assigned to organisms represented in cultures (Table 2). The AD3-affiliated phylotype was 99\% similar to A10G4 (Figure 5, Table 2) from an acidophilic Fe(II) oxidizing enrichment culture (Wu et al., 2013). The most abundant Acidobacterial phylotype detected in the iron mound sediments was 99\% similar to sequences detected in an AMD impacted system, and 97\% similar to an aerobic acidophlic organotrophic organism CH1 (Diaby et al., 2007), though it is unclear if this organism might be capable of anaerobic metabolism. More 
detailed taxonomic analysis of Firmicutes-affiliated phylotypes revealed shifts in the evolutionary lineages to which they could be assigned (Figure 5, Table 2). In the upper $4 \mathrm{~cm}$ of the iron mound, Firmicutes-affiliated phylotypes were similar to the acidophilic FeOB iFeo-D4-31-CH (Figure 5, Table 2) that was isolated from an AMD-impacted lake sediments and is also capable of $\mathrm{Fe}$ (III) reduction (Lu et al., 2010). The isolate iFeo-D4-31-CH and several other isolates from the same system were attributable to Alicyclobacillus spp., as was $\mathrm{OTU}_{0.03} 32$, which was abundant throughout the depth of the MF iron mound (Figure 5, Table 2). An OTU 0.03 attributable to the acid-tolerant sulfate- and Fe(III)-reducing bacterium Desulfosporosinus GBSRB4.2, which was isolated from iron mound sediments (Senko et al., 2009), was detected in the lower $2 \mathrm{~cm}$ of the iron mound sediments (Figure 5, Table 2).

\section{BIOGEOCHEMICAL PROCESSES ASSOCIATED WITH MF IRON MOUND SEDIMENTS}

Geochemical characterization of iron mound sediments indicated redox cycling of Fe was occurring in the MF iron mound, and microbiological characterization of the iron mound system revealed communities capable of $\mathrm{Fe}$ metabolism regardless of depth. At the MF, vertical growth of the iron mound [by $\mathrm{Fe}$ (III) (hydr)oxide deposition] is mediated by the activities of aerobic FeOB near the sediment-AMD interface, supported by $\mathrm{O}_{2}$ produced by phototrophic microeukaryotes and diffusing into the AMD from the atmosphere. Organic carbon appears to be derived from phototrophic microeukaryotic activities, and perhaps autotrophic FeOB activities near the iron mound-AMD interface. With progressively greater depth, we observed depletion of $\mathrm{O}_{2}$, and FeRB activities gave rise to a peak in porewater $\mathrm{Fe}(\mathrm{II})$ concentration at approximately $2.5 \mathrm{~cm}$ below the sedimentAMD inferface (Figure 1A). This region of the iron mound is also where the transformation of poorly crystalline Fe(III) phases to goethite occurred (Figure 2), which was likely induced by FeRB activities (Hansel et al., 2003; Burton et al., 2007; Bertel et al., 2012). However, it is notable that the region of maximal $\mathrm{Fe}$ (III) reduction [as indicated by maximal porewater $\mathrm{Fe}$ (II) concentration] was not completely depleted in $\mathrm{O}_{2}$, and culturable FeRB were most abundant in the upper regions of the iron mound (Figures 1A,B,D). This indicates a co-occurrence of both $\mathrm{O}_{2}$ and $\mathrm{Fe}(\mathrm{III})$ reduction within the iron mound sediments. Thus far, no obligately anaerobic and Fe(III)-respiring bacteria have been isolated from AMD-impacted systems. Those that have been recovered in culture are facultative anaerobes (Johnson and McGinness, 1991; Pronk et al., 1992; Küsel et al., 1999). Indeed, acidophilic, organotrophic Acidiphilium spp. exhibit more robust $\mathrm{Fe}$ (III)-reducing activities under microaerobic conditions rather than under strictly anaerobic conditions (Küsel et al., 2002; Malki et al., 2008), and close association of FeOB and FeRB activities has been recently reported in circumneutral settings (Elliott et al., 2014).

Characterization of microbial communities at various depths within the iron mound sediments indicated transitions within the microbial communities with depth, with a demarcation between the communities above and below $4 \mathrm{~cm}$ (Figure 3 ), and phylotypes attributable to lineages of anaerobic microorganisms below this point (Figure 5). However, culturable organotrophic FeRB abundances were highest at the $2 \mathrm{~cm}$ depth interval and decreased with depth (Figure 1E), while dissolved $\mathrm{Fe}(\mathrm{II})$ was depleted between 3 and $5 \mathrm{~cm}$ (and remained relatively low below $5 \mathrm{~cm}$; Figure 1A). Similarly, the most dramatic decrease in sulfate concentration occurred at the sediment-AMD interface [likely due to incorporation of sulfate into biogenic $\mathrm{Fe}$ (III) phases], and no sulfate depletion was evident in deeper regions of the sediments, suggesting minimal sulfate reducing bacterial (SRB) activity (Figure 1C). No black FeS phases were observed in the sediment cores, and FeS phases (e.g., mackinawite or greigite) could not be detected by XRD, but it is likely that sulfide accumulation in the sediments would be minimal due to rapid oxidation of biogenic sulfide by $\mathrm{Fe}(\mathrm{III})$ phases in the iron mound sediments (dos Santos Afonso and Stumm, 1992). The organic carbon content of the sediments below $4 \mathrm{~cm}$ (approximately $2 \mathrm{mg} / \mathrm{g}$ sediment; $0.1 \mathrm{mmol} \mathrm{CH}_{2} \mathrm{O} / \mathrm{g}$ ) is sufficient to support the reductive dissolution of $\mathrm{Fe}$ (III), yielding over $100 \mathrm{mM} \mathrm{Fe}$ (II) in porewater, and at relatively low $\mathrm{pH}$, the thermodynamic favorability of goethite-Fe(III) reduction would likely be enhanced (Bethke et al., 2011). Taken together, these results indicate less anaerobic respiratory activity [i.e., $\mathrm{Fe}$ (III) and sulfate reduction] in the MF sediments below approximately $3 \mathrm{~cm}$, despite depletion of $\mathrm{O}_{2}$ below this point.

As such, the demarcation between aerobic and anaerobic communities within the iron mound sediments appears to be somewhat nebulous. Total cell abundances were uniform throughout the iron mound sediments (Figure 1E), despite minimal evidence of anaerobic respiratory activities in the deeper, $\mathrm{O}_{2}$-depleted portions of the sediments. Similarly, relatively uniform abundances of culturable FeOB (Figure 1E) were detected throughout the iron mound (Figure 1E). The most abundant phylotype detected in the iron mound (comprising $\geq 20 \%$ of sequences, regardless of depth) was attributable to a lineage of acidophilic bacteria capable of aerobic Fe(II) oxidation and anaerobic Fe(III) reduction, and phylotypes attributable to aerobic FeOB Leptospirillum spp. and Acidithiobacillus spp. were most abundant in sequence libraries derived from iron mound sediments at depth intervals below $3 \mathrm{~cm}$ (Figure 5, Table 2). Aqueous Fe(II) was depleted below the region of complete $\mathrm{O}_{2}$ depletion, and remained at a relatively low concentration in deeper regions of the iron mound, despite sufficient organic carbon to support abundant $\mathrm{Fe}$ (III) reduction (Figures 1A,B,D). Removal of aqueous Fe(II) by adsorption is an unlikely mechanism of dissolved Fe(II) depletion at depths below $3 \mathrm{~cm}$, because solid associated $\mathrm{Fe}$ (II) was similarly depleted at depth within the iron mound sediments (Figure 1A). As such, it appears that the depletion of dissolved $\mathrm{Fe}$ (II) and maintenance of relatively low $\mathrm{Fe}$ (II) concentrations is attributable to $\mathrm{Fe}(\mathrm{II})$ oxidation. A similar pattern of $\mathrm{Fe}(\mathrm{II})$ oxidation at depth has been observed in a similar system, but in that case, Fe(II) oxidation was supported by $\mathrm{O}_{2}$ delivered by interstitial water flow (Larson et al., 2013). However, in the case presented here, $\mathrm{O}_{2}$ was not detected in deeper sediments where $\mathrm{Fe}(\mathrm{II})$ oxidation appeared to occur, so it is unclear how this might be accomplished in the absence of light or chemical oxidants (e.g., nitrate or $\mathrm{O}_{2}$ ). Oxidation of $\mathrm{Fe}(\mathrm{II})$ in $\mathrm{O}_{2}$-depleted portions of the iron mound may be facilitated by extracellular electron transfer processes to oxic portions 
of the iron mound (Ntarlagiannis et al., 2009; Nielsen et al., 2010; Roden et al., 2010; Kato et al., 2012; Risgaard-Petersen et al., 2012), and such processes will be further explored in iron mound settings. This work illustrate that while the initial development and upward growth of the iron mound is mediated by $\mathrm{FeOB}$ with ready access to $\mathrm{O}_{2}, \mathrm{Fe}$ (III) bioreduction also occurs in oxic portions of the iron mound, but $\mathrm{Fe}$ (II) oxidation can be sustained at $\mathrm{O}_{2}$-depleted depths within the sediments.

\section{ACKNOWLEDGMENTS}

This work was funded by National Science Foundation (NSF) EAR Geobiology and Low Temperature Geochemistry Program award number 0851847 . Christopher M. Menge was partially supported by a grant from NSF DUE award number 1226175. We thank Cheryl Socotch from the Ohio Department of Natural Resources for introducing us to the Mushroom Farm system and for valuable background information on site. We are grateful to John Wilson, the Mushroom Farm landowner, for granting us access to the site. The contributions of Amy Milsted (UA Department of Biology) to this work are gratefully acknowledged. We thank Hazel Barton and Michael Johnston (UA Department of Biology) for access to microscopy facilities and assistance with fluorescence microscopy.

\section{REFERENCES}

Aguilera, A., Souza-Egipsy, V., Gómez, F., and Amils, R. (2007). Development and structure of eukaryotic biofilms in an extreme acidic environment, Rio Tinto (SW, Spain). Microb. Ecol. 53, 294-305. doi: 10.1007/s00248-0069092-2

Alazard, D., Joseph, M., Battaglia-Brunet, F., Cayol, J. L., and Ollivier, B. (2010). Desulfosporosinus acidiphilus sp. nov.: a moderately acidophilic sulfate-reducing bacterium isolated from acid mining drainage sediments. Extremophiles 14, 305-312. doi: 10.1007/s00792-010-0309-4

Alonso-Gutiérrez, J., Figueras, A., Albaigés, J., Jiménez, N., Viñas, M., Solanas, A. M., et al. (2009). Bacterial communities from shoreline environments (costa da morte, northwestern Spain) affected by the prestige oil spill. Appl. Environ. Microbiol. 75, 3407-3418. doi: 10.1128/AEM.01776-08

Altschul, S. F., Madden, T. L., Schaffer, A. A., Zhang, J., Zhang, Z., Miller, W., et al. (1997). Gapped BLAST and PSI-BLAST: a new generation of protein database search programs. Nucl. Acid Res. 25, 3389-3402. doi: 10.1093/nar/25.17.3389

Amaral-Zettler, L., Zettler, E. R., Theroux, S. M., Palacios, C., Aguilera, A., and Amils, R. (2011). Microbial community structure across the tree of life in the extreme Río Tinto. ISME J. 5, 42-50. doi: 10.1038/ismej.2010.101

Baker, B. J., and Banfield, J. F. (2003). Microbial communities in acid mine drainage. FEMS Microbiol. Ecol. 44, 139-152. doi: 10.1016/S0168-6496(03)00028-X

Bertel, D., Peck, J., Quick, T. J., and Senko, J. M. (2012). Iron transformations induced by an acid-tolerant Desulfosporosinus species. Appl. Environ. Microbiol. 78, 81-88. doi: 10.1128/AEM.06337-11

Bethke, C. M., Sanford, R., Kirk, M. F., Jin, Q., and Flynn, T. M. (2011). The thermodynamic ladder in geomicrobiology. Am. J. Sci. 311, 183-210. doi: 10.2475/03.2011.01

Bigham, J. M., Schwertmann, U., Carlson, L., and Murad, E. (1990). A poorly crystallized oxyhy- droxysulfate of iron formed by bacterial oxidation of Fe(ll) in acid mine waters. Geochim. Cosmochim. Acta 54, 2743-2758. doi: 10.1016/00167037(90)90009-A

Bigham, J. M., Schwertmann, U., and Pfab, G. (1996a). Influence of pH on mineral speciation in a bioreactor simulating acid mine drainage. Appl. Geochem. 11, 845-849. doi: 10.1016/S0883-2927(96)00052-2

Bigham, J. M., Schwertmann, U., Traina, S. J., Winland, R. L., and Wolf, M. (1996b). Schwertmannite and the chemical modeling of iron in acid sulfate waters. Geochim. Cosmochim. Acta 60, 2111-2121. doi: 10.1016/0016-7037(96)00091-9

Bohorquez, L. C., Delgado-Serrano, L., López, G., Osorio-Forero, C., KlepacCeraj, V., Junca, H., et al. (2012). In-depth characterization via complementing culture-independent approaches of the microbial community in an acidic hot spring of the Colombian Andes. Microb. Ecol. 63, 103-115. doi: 10.1007/s00248011-9943-3

Brake, S. S., and Hasiotis, S. T. (2010). Eukaryote-dominated biofilms and their significance in acidic environments. Geomicrobiol. J. 27, 534-558. doi: 10.1080/01490451003702966

Brake, S. S., Hasiotis, S. T., and Dannelly, H. K. (2004). Diatoms in acid mine drainage and their role in the formation of iron-rich stromatolites. Geomicrobiol. J. 21, 331-340. doi: 10.1080/01490450490454074

Brofft, J. E., McArthur, J. V., and Shimkets, L. J. (2002). Recovery of novel bacterial diversity from a forested wetland impacted by reject coal. Environ. Microbiol. 4, 764-769. doi: 10.1046/j.1462-2920.2002.00337.x

Brown, J. F., Jones, D. S., Mills, D. B., Macalady, J. L., and Burgos, W. D. (2011). Application of a depositional facies model to an acid mine drainage site. Appl. Environ. Microbiol. 77, 545-554. doi: 10.1128/AEM.01550-10

Burgos, W. D., Borch, T., Troyer, L. D., Luan, F., Larson, L. N., Brown, J. F., et al. (2012). Schwertmannite and Fe oxides formed by biological low-pH Fe(II) oxidation versus abiotic neutralization: impact on trace metal sequestration. Geochim. Cosmochim. Acta 76, 29-44. doi: 10.1016/j.gca.2011.10.015

Burton, E. D., Bush, R. T., Sullivan, L., and Mitchell, D. R. G. (2007). Reductive transformation of iron and sulfur in schwertmannite-rich accumulations associated with acidified coastal lowlands. Geochim. Cosmochim. Acta 71, 4456-4473. doi: 10.1016/j.gca.2007.07.007

Caporaso, J. G., Kuczynski, J., Stombaugh, J., Bittinger, K., Bushman, F. D., Costello, E. K., et al. (2011). QIIME allows analysis of high-throughput community sequencing data. Nat. Methods 7, 335-336. doi: 10.1038/nmeth.f.303

Cavaletti, L., Monciardini, P., Bamonte, R., Schumann, P., Rohde, M., Sosio, M., et al. (2006). New lineage of filamentous, spore-forming, gram-positive bacteria from soil. Appl. Environ. Microbiol. 72, 4360-4369. doi: 10.1128/AEM.00132-06

Coates, J. D., Cole, K. A., Chakraborty, R., O’Connor, S. M., and Achenbach, L. A. (2002). Diversity and ubiquity of bacteria capable of utilizing humic substances as electron donors for anaerobic respiration. Appl. Environ. Microbiol. 68, 2445-2452. doi: 10.1128/AEM.68.5.2445-2452.2002

Cole, J. R., Wang, Q., Cardenas, E., Fish, J., Chai, B., Farris, R. J., et al. (2009). The Ribosomal Database Project: improved alignments and new tools for rRNA analysis. Nucleic Acids Res. 37, D141-D145. doi: 10.1093/nar/gkn879

Colwell, R. R. (1979). "Enumeration of specific populations by most-probablenumber (MPN) method," in Native Aquatic Bacteria: Enumeration, Activity, and Ecology, eds J. W. Costerton and R. R. Colwell (Philadelphia, PA: American Society for Testing and Materials), 56-61. doi: 10.1520/STP36003S

Coupland, K., and Johnson, D. B. (2008). Evidence that the potential for dissimilatory ferric iron reduction is widespread among acidophilic heterotrophic bacteria. FEMS Microbiol. Lett. 279, 30-35. doi: 10.1111/j.1574-6968.2007.00998.x

Cravotta, C. A. III. (2008). Dissolved metals and associated constituents in abandoned coal-mine discharges, Pennsylvania, USA Part 1: constituent quantities and correlations. Appl. Geochem. 23, 166-202. doi: 10.1016/j.apgeochem.2007. 10.011

Dalvi, S., Azetsu, S., Patrauchan, M., Aktas, D. F., and Fathepure, B. Z. (2012). Proteogenomic elucidation of the initial steps in the benzene degradation pathway of a novel halophile, Arhodomonas sp. strain Rozel, isolated from a hypersaline environment. Appl. Environ. Microbiol. 78, 7309-7316. doi: 10.1128/ AEM.01327-12

De la Torre, J. R., Walker, C. B., Ingalls, A. E., Könneke, M., and Stahl, D. (2008). Cultivation of a thermophilic ammonia oxidizing archaeon synthesizing crenarchaeol. Environ. Microbiol. 10, 810-818. doi: 10.1111/j.1462-2920.2007. 01506.x

Delavat, F., Lett, M.-C., and Lièvremont, D. (2012). Novel and unexpected bacterial diversity in an arsenic-rich ecosystem revealed by culture dependent approaches. Biol. Direct. 7, 28. doi: 10.1186/1745-6150-7-28

DeSa, T. C., Brown, J. F., and Burgos, W. D. (2010). Laboratory and field-scale evaluation of low-pH oxidation at Hughes Borehole, Portage, Pennsylvania. Mine Wat. Environ. 29, 239-247. doi: 10.1007/s10230-010-0105-5

DeSantis, T. Z., Hugenholtz, P., Larsen, N., Rojas, M., Brodie, E. L., Keller, K., et al. (2006). Greengenes, a chimera-checked 16S rRNA gene database and workbench compatible with ARB. Appl. Environ. Microbiol. 72, 5069-5072. doi: 10.1128/AEM.03006-05

Diaby, N., Dold, B., Pfeifer, H.-R., Holliger, C., Johnson, D. B., and Hallberg, K. B. (2007). Microbial communities in a porphyry copper tailings impoundment and their impact on the geochemical dynamics of the mine waste. Environ. Microbiol. 9, 298-307. doi: 10.1111/j.1462-2920.2006.01138.x 
dos Santos Afonso, M., and Stumm, W. (1992). Reductive dissolution of iron(III) (hydr)oxides by hydrogen sulfide. Langmuir 8, 1671-1675. doi: 10.1021/la00042a030

Downs, R. T., and Hall-Wallace, M. (2003). The American mineralogist crystal structure database. Am. Mineral. 88, 247-250.

Dridi, B., Fardeau, M.-L., Ollivier, B., Raoult, D., and Drancourt, M. (2012). Methanomassiliicoccus luminyensis gen. nov., sp. nov., a methanogenic archaeon isolated from human faeces. Int. J. Syst. Evol. Microbiol. 62, 1902-1907. doi: 10.1099/ijs.0.033712-0

Edgar, R. C. (2010). Search and clustering orders of magnitude faster than BLAST. Bioinformatics 26, 2460-2461. doi: 10.1093/bioinformatics/btq461

Edwards, K. J., Bond, P. L., Gihring, T. M., and Banfield, J. F. (2000). An archaeal iron-oxidizing extreme acidophile important in acid mine drainage. Science 287, 1796-1799. doi: 10.1126/science.287.5459.1796

Elliott, A. V. C., Plach, J. M., Droppo, I. G., and Warren, L. A. (2014). Collaborative microbial Fe-redox cycling by pelagic floc bacteria across wide ranging oxygenated aquatic systems. Chem. Geol. 366, 90-102. doi: 10.1016/j.chemgeo.2013. 11.017

Emerson, D., Fleming, E. J., and McBeth, J. M. (2010). Iron-oxidizing bacteria: an environmental and genomic perspective. Annu. Rev. Microbiol. 64, 561-583. doi: 10.1146/annurev.micro.112408.134208

Fahrbach, M., Kuever, J., Remesch, M., Huber, B. E., Kämpfer, P., Dott, W., et al. (2008). Steroidobacter denitrificans gen. nov., sp. nov., a steroidal hormonedegrading gammaproteobacterium. Int J. Syst. Evol. Microbiol. 58, 2215-2223. doi: 10.1099/ijs.0.65342-0

Falteisek, L., and Cepička, I. (2012). Microbiology of diverse acidic and nonacidic microhabitats within a sulfidic ore mine. Extremophiles 16, 911-922. doi: 10.1007/s00792-012-0488-2

Fleming, E. J., Langdon, A. E., Martinez-Garcia, M., Stepanauskas, R., Poulton, N. J., Masland, E. D. P., et al. (2011). What's new is old: resolving the identity of Leptothrix ochracea using single cell genomics, pyrosequencing and FISH. PLoS ONE 6:17769. doi: 10.1371/journal.pone.0017769

Fujimura, R., Sato, Y., Nishizawa, T., Oshima, K., Kim, S.-W., Hattori, M., et al. (2012). Complete genome sequence of Leptospirillum ferrooxidans strain C23 , isolated from a fresh volcanic ash deposit on the island of Miyake, Japan. J. Bacteriol. 194, 4122-4123. doi: 10.1128/JB.00696-12

Gan, Y., Qiu, Q., Liu, P., Rui, J., and Lu, Y. (2012). Syntrophic oxidation of propionate in rice field soil at 15 and $30^{\circ} \mathrm{C}$ under methanogenic conditions. Appl. Environ. Microbiol. 78, 4923-4932. doi: 10.1128/AEM.00688-12

García-Moyano, A., González-Toril, E., Aguilera, Á., and Amils, R. (2012). Comparative microbial ecology study of the sediments and the water column of the Río Tinto, an extreme acidic environment. FEMS Microbiol. Ecol. 81, 303-314. doi: 10.1111/j.1574-6941.2012.01346.x

Golyshina, O. V., Pivovarova, T. A., Karavaiko, G. I., Kondrat, T. F., Moore, E. R. B., Abraham, W., et al. (2000). Ferroplasma acidiphilum gen. nov., sp. nov., an cellwall-lacking, mesophilic member of the Ferroplasmaceae fam. nov., comprising a distinct lineage of the Archaea. Int. J. Syst. Evol. Microbiol. 50, 997-1006. doi: 10.1099/00207713-50-3-997

Gomez-Alvarez, V., King, G. M., and Nüsslein, K. (2007). Comparative bacterial diversity in recent Hawaiian volcanic deposits of different ages. FEMS Microbiol. Ecol. 60, 60-73. doi: 10.1111/j.1574-6941.2006.00253.x

Gontcharova, V. Y., Wolcott, R. D., Hollister, E. B., Gentry, T. J., and Dowd, S. E. (2010). Black Box Chimera Check (B2C2): a windows-based software for batch depletion of chimeras from bacterial 16S rRNA gene datasets. Open Microbiol. J. 4, 6. doi: 10.2174/1874285801004010047

González-Toril, E., Llobet-Brossa, E., Casamayor, E. O., Amann, R., and Amils, R. (2003). Microbial ecology of an extreme acidic environment, the Tinto River. Appl. Environ. Microbiol. 69, 4853-4865. doi: 10.1128/AEM.69.8.48534865.2003

Gouin, M., Saracusa, E., Clemons, C. B., Senko, J., Kreider, K. L., and Young, G. W. (2013). A mathematical model of a passive scheme for acid mine drainage remediation. GEM - Int. J. Geomath. 4, 27-53. doi: 10.1007/s13137-012-0044-3

Guo, X., Yin, H., Cong, J., Dai, Z., Liang, Y., and Liu, X. (2013). RubisCO gene clusters found in a metagenome microarray from acid mine drainage. Appl. Environ. Microbiol. 79, 2019-2026. doi: 10.1128/AEM.03400-12

Hahn, M. W., Stadler, P., Wu, Q. L., and Pöckl, M. (2004). The filtrationacclimatization method for isolation of an important fraction of the not readily cultivable bacteria. J. Microbiol. Methods 57, 379-390. doi: 10.1016/j.mimet.2004.02.004
Hallberg, K. B., Coupland, K., Kimura, S., and Johnson, D. B. (2006). Macroscopic streamer growths in acidic, metal-rich mine waters in north wales consist of novel and remarkably simple bacterial communities. Appl. Environ. Microbiol. 72, 2022-2030. doi: 10.1128/AEM.72.3.2022-2030.2006

Hallberg, K. B., and Johnson, D. B. (2003). Novel acidophiles isolated from moderately acidic mine drainage waters. Hydrometallurgy 71, 139-148. doi: 10.1016/S0304-386X(03)00150-6

Hansel, C. M., Benner, S. D., Neiss, J., Dohnalkova, A., Kukkadapu, R. K., and Fendorf, S. (2003). Secondary mineralization pathways induced by dissimilatory iron reduction of ferrihydrite under advective flow. Geochim. Cosmochim. Acta 67, 2977-2992. doi: 10.1016/S0016-7037(03)00276-X

Hao, C., Wang, L., Gao, Y., Zhang, L., and Dong, H. (2010). Microbial diversity in acid mine drainage of Xiang Mountain sulfide mine, Anhui Province, China. Extremophiles 14, 465-474. doi: 10.1007/s00792-010-0324-5

Hedrich, S., Heinzel, E., Seifert, J., and Schlöman, M. (2009). Isolation of novel iron-oxidizing bacteria from an acid mine water treatment plant. Adv. Mat. Res. 71-73, 125-128. doi: 10.4028/www.scientific.net/AMR.71-73.125

Hedrich, S., Schlömann, M., and Johnson, D. B. (2011). The iron-oxidizing proteobacteria. Microbiology 157, 1551-1564. doi: 10.1099/mic.0.045344-0

Heinzel, E., Hedrich, S., Janneck, E., Glombitza, F., Seifert, J., and Schlömann, M. (2009). Bacterial diversity in a mine water treatment plant. Appl. Environ. Microbiol. 75, 858-861. doi: 10.1128/AEM.01045-08

Hengstmann, U., Chin, K.-J., Janssen, P. H., and Liesack, W. (1999). Comparative phylogenetic assignment of environmental sequences of genes encoding $16 \mathrm{~S}$ rRNA and numerically abundant culturable bacteria from an anoxic rice paddy soil. Appl. Environ. Microbiol. 65, 5050-5058.

Itoh, T., Yamanoi, K., Kudo, T., Ohkuma, M., and Takashina, T. (2011). Aciditerrimonas ferrireducens gen. nov., sp. nov., an iron-reducing thermoacidophilic actinobacterium isolated from a solfataric field. Int. J. Syst. Evol. Microbiol. 61, 1281-1285. doi: 10.1099/ijs.0.023044-0

Jang, J.-H., Mathur, R., Liermann, L. J., Ruebush, S., and Brantley, S. L. (2008) An iron isotope signature related to electron transfer between aquesou ferrous iron and goethite. Chem. Geol. 250, 40-48. doi: 10.1016/j.chemgeo.2008. 02.002

Jeon, B.-H., Dempsey, B. A., Burgos, W. D., and Royer, R. A. (2003). Soprtion kinetics of $\mathrm{Fe}(\mathrm{II}), \mathrm{Zn}(\mathrm{II}), \mathrm{Co}(\mathrm{II}), \mathrm{Ni}(\mathrm{II}), \mathrm{Cd}(\mathrm{II})$, and $\mathrm{Fe}(\mathrm{II}) / \mathrm{Me}(\mathrm{II})$ onto hematite. Wat. Res. 37, 4135-4142. doi: 10.1016/S0043-1354(03)00342-7

Johnson, D. B. (1995). Selective solid media for isolating and enumerating acidophilic bacteria. J. Microbiol. Methods 23, 205-218. doi: 10.1016/01677012(95)00015-D

Johnson, D. B., and Hallberg, K. B. (2002). Pitfalls of passive mine water treatment. Rev. Environ. Sci. Biotechnol. 1, 335-343. doi: 10.1023/A:1023219300286

Johnson, D. B., and McGinness, S. (1991). Ferric iron reduction by acidophilic heterotrophic bacteria. Appl. Environ. Microbiol. 57, 207-211.

Kato, S., Hashimoto, K., and Watanabe, K. (2012). Microbial interspecies electron transfer via electric currents through conductive minerals. Proc. Nat. Acad. Sci. U.S.A. 109, 10042-10046. doi: 10.1073/pnas.1117592109

Kay, C., Rowe, O., Rocchetti, L., Coupland, K., Hallberg, K., and Johnson, D. (2013). Evolution of microbial "streamer" growths in an acidic, metal-contaminated stream draining an abandoned underground copper mine. Life 3, 189-211. doi: 10.3390/life3010189

Kopecky, J., Kyselkova, M., Omelka, M., Cermak, L., Novotna, J., Grundmann, G., et al. (2011). Environmental mycobacteria closely related to the pathogenic species evidenced in an acidic forest wetland. Soil. Biol. Biochem. 43, 697-700. doi: 10.1016/j.soilbio.2010.11.033

Küsel, K., Dorsch, T., Acker, G., and Stackenbrandt, E. (1999). Microbial reduction of Fe(III) in acidic sediments: isolation of Acidiphilium cryptum JF-5 capable of coupling reduction of $\mathrm{Fe}$ (III) to oxidation of glucose. Appl. Environ. Microbiol. 65, 3633-3640.

Küsel, K., Roth, U., and Drake, H. L. (2002). Microbial reduction of Fe(III) in the presence of oxygen under low pH conditions. Environ. Microbiol. 4, 414-421. doi: 10.1046/j.1462-2920.2002.00314.x

Larouche, J. R., Bowden, W. B., Giordano, R., Flinn, M. B., and Crump, B. C. (2012). Microbial biogeography of arctic streams: exploring influences of lithology and habitat. Front. Microbiol. 3:309. doi: 10.3389/fmicb.2012.00309

Larson, L. N., Fitzgerals, M., Singha, K., Gooseff, M. N., Macalady, J. L., and Burgos, W. D. (2013). Hydrochemical niches associated with hyporheic exchange beneath an acid mine drainage contaminated system. J. Hydrol. 501, 163-174. doi: 10.1016/j.jhydrol.2013.08.007 
Liljeqvist, M., Valdes, J., Holmes, D. S., and Dopson, M. (2011). Draft genome of the psychrotolerant acidophile Acidithiobacillus ferrivorans SS3. J. Bacteriol. 193, 4304-4305. doi: 10.1128/JB.05373-11

Lima, L. J. R., van der Velpen, V., Wolkers-Rooijackers, J., Kamphuis, H. J., Zwietering, M. H., and Nout, M. J. R. (2012). Microbiota dynamics and diversity at different stages of industrial processing of cocoa beans into cocoa powder. Appl. Environ. Microbiol. 78, 2904-2913. doi: 10.1128/AEM.07691-11

Lin, X., Green, S., Tfaily, M. M., Prakash, O., Konstantinidis, K. T., Corbett, J. E., et al. (2012). Microbial community structure and activity linked to contrasting biogeochemical gradients in bog and fen environments of the Glacial Lake Agassiz Peatland. Appl. Environ. Microbiol. 78, 7023-7031. doi: 10.1128/AEM.01750-12

Lovley, D. R., and Phillips, E. J. P. (1987). Rapid assay for microbially reducible ferric iron in aquatic sediments. Appl. Environ. Microbiol. 53, 1536-1540.

Lozupone, C. A., Hamady, M., Kelly, S. T., and Knight, R. (2007). Quantitative and qualitative $\beta$ diversity measures lead to different insights into factors that structure microbial communities.. Appl. Environ. Microbiol. 73, 1576-1585. doi: 10.1128/AEM.01996-06

Lu, S., Chourey, K., Reiche, M., Nietzsche, S., Shah, M. B., Neu, T. R., et al. (2013). Insights into the structure and metabolic function of microbes that shape pelagic iron-rich aggregates (“iron snow”). Appl. Environ. Microbiol. 79, 4272-4281. doi: 10.1128/AEM.00467-13

Lu, S., Gischkat, S., Reiche, M., Akob, D. M., Hallberg, K. B., and Küsel, K. (2010). Ecophysiology of Fe-cycling bacteria in acidic sediments. Appl. Environ. Microbiol. 76, 8174-83. doi: 10.1128/AEM.01931-10

Lucheta, A. R., Otero, X. L., Macías, F., and Lambais, M. R. (2013). Bacterial and archaeal communities in the acid pit lake sediments of a chalcopyrite mine. Extremophiles 17, 941-951. doi: 10.1007/s00792-013-0576-y

Malki, M., De Lacey, A. L., Rodríguez, N., Amils, R., and Fernandez, V. M. (2008). Preferential use of an anode as an electron acceptor by an acidophilic bacterium in the presence of oxygen. Appl. Environ. Microbiol. 74, 4472-4476. doi: 10.1128/AEM.00209-08

Milanowski, R., Kosmala, S., Zakrys, B., and Kwiatowski, J. (2006). Phylogeny of photosynthetic Euglenophytes based on combined chloroplast and cytoplasmic SSU rDNA sequence analysis. J. Phycol. 42, 721-730. doi: 10.1111/j.15298817.2006.00216.x

Murmatsu, H., Murakami, R., Ibrahim, Z. H., Murakami, K., Shahab, N., and Nagai, K. (2011). Phylogenetic diversity of acidophilic actinoycetes from Malaysia. J. Antibiotics. 64, 621-624. doi: 10.1038/ja.2011.57

Neal, A. L., Techarnjanaruk, S., Dohnalkova, A., McCready, D., Peyton, B. M., and Geesey, G. G. (2001). Iron sulfides and sulfur species produced at hematite surfaces in the presence of sulfate-reducing bacteria. Geochim. Cosmochim. Acta 65, 223-235. doi: 10.1016/S0016-7037(00)00537-8

Nepomnyashchaya, Y. N., Slobodkina, G. B., Baslerov, R. V., Chernyh, N. A., BonchOsmolovskaya, E. A., Netrusov, A. I., et al. (2012). Moorella humiferrea sp. nov., a thermophilic, anaerobic bacterium capable of growth via electron shuttling between humic acid and Fe(III). Int. J. Syst. Evol. Microbiol. 62, 613-617. doi: 10.1099/ijs.0.029009-0

Nicomrat, D., Dick, W. A., and Tuovinen, O. H. (2006). Assessment of the microbial community in a constructed wetland that receives acid coal mine drainage. Microbiol. Ecol. 51, 83-89. doi: 10.1007/s00248-005-0267-z

Nielsen, L. P., Risgaard-Petersen, N., Fossing, H., Christensen, P. B., and Sayama, M. (2010). Electric currents couple spatially separated biogeochemical processes in marine sediment. Nature 463, 1071-1074. doi: 10.1038/nature08790

Ntarlagiannis, D., Atekwana, E. A., Hill, E. A., and Gorby, Y. (2009). Microbial nanowires: is the subsurface "hardwired"? Geophys. Res. Lett. 34, L17305. doi: 10.1029/2007GL030426

Parfitt, R. L., and Smart, R. St. C. (1977). The mechanism of sulfate adsorption on iron oxides. Soil Sci. Soc. Am. J. 42, 48-50. doi: 10.2136/sssaj1978.03615995004 $200010011 x$

Pillet, L., de Vargas, C., and Pawlowski, J. (2011). Molecular identification of sequestered diatom chloroplasts and kleptoplastidy in foraminifera. Protist 162, 394-404. doi: 10.1016/j.protis.2010.10.001

Poulton, S. W., Krom, M. D., and Raiswell, R. (2004). A revised scheme for the reactivity of iron (oxyhydr)oxide minerals towards dissolved sulfide. Geochim. Cosmochim. Acta 68, 3703-3715. doi: 10.1016/j.gca.2004.03.012

Pronk, J. T., de Bruyn, J. C., Bos, P., and Kuenen, J. G. (1992). Anaerobic growth of Thiobacillus ferrooxidans. Appl. Environ. Microbiol. 58, 2227-2230.
Qiu, Y.-L., Sekiguchi, Y., Imachi, H., Kamagata, Y., Tseng, I.-C., Cheng, S.-S., and Ohashi, H. H. (2004). Identification and isolation of anaerobic, syntrophic p-phthalate isomers-degrading microbes from methanogenic sludges treating wastewater from terephthalate manufacturing. Appl. Environ. Microbiol. 70, 1617-1626. doi: 10.1128/AEM.70.3.1617-1626.2004

Regenspurg, S., Brand, A., and Peiffer, S. (2004). Formation and stability of schwertmannite in acidic mining lakes. Geochim. Cosmochim. Acta 68, 1185-1197. doi: 10.1016/j.gca.2003.07.015

Risgaard-Petersen, N., Revil, A., Meister, P., and Nielsen, L. P. (2012). Sulfur, iron-, and calcium cycling associated with natural electric currents running through marine sediment. Geochim. Cosmochim. Acta 92, 1-13. doi: 10.1016/j.gca.2012.05.036

Roden, E. E., Kappler, A., Bauer, I., Jiang, J., Paul, A., Stoesser, R., et al. (2010). Extracellular electron transfer through microbial reduction of solid-phase humic substances. Nat. Geosci. 3, 417-421. doi: 10.1038/ngeo870

Rowe, O. F., Sánchez-España, J., Hallberg, K. B., and Johnson, D. B. (2007). Microbial communities and geochemical dynamics in an extremely acidic, metal-rich stream at an abandoned sulfide mine (Huelva, Spain) underpinned by two functional primary production systems. Environ. Microbiol. 9, 1761-1771. doi: 10.1111/j.1462-2920.2007.01294.x

Ryzinska-Paier, G., Sommer, R., Haider, J. M., Knetsch, S., Frick, C., Kirschner, K. T., et al. (2011). Acid phosphatase test proves superior to standard phenotypic identification procedure for Clostridium perfringens strains isolated from water. J. Microbiol. Methods 87, 189-194. doi: 10.1016/j.mimet.2011.08.006

Sahl, J. W., Schmidt, R., Swanner, E. D., Mandernack, K. W., Templeton, A. S., Kieft, T. L., et al. (2008). Subsurface microbial diversity in deep-granitic-fracture water in Colorado. Appl. Environ. Microbiol. 74, 143-152. doi: 10.1128/AEM.01133-07

Sánchez-Andrea, I., Rodríguez, N., Amils, R., and Sanz, J. L. (2011). Microbial diversity in anaerobic sediments at Rio Tinto, a naturally acidic environment with a high heavy metal content. Appl. Environ. Microbiol. 77, 6085-6093. doi: 10.1128/AEM.00654-11

Sánchez España, J., Santofimia, Pastor, E., and López Pamo, E. (2007). Iron terraces in acid mine drainage systems: a discussion about the organic and inorganic factors involved in their formation through observations from the Tintillo acidic river (Rio Tinto Mine, Huelva, Spain). Geosphere 3, 133. doi: 10.1130/GES00069.1

Santofimia, E., González-Toril, E., López-Pamo, E., Gomariz, M., Amils, R., and Aguilera, A. (2013). Microbial diversity and its relationship to physicochemical characteristics of the water in two extreme acidic pit lakes from the Iberian pyrite belt (SW Spain). PLoS ONE 8:66746. doi: 10.1371/journal.pone.0066746

Satoh, A., Watanabe, M., Ueki, A., and Ueki, K. (2002). Physiological properties and phylogenetic affiliations of anaerobic bacteria isolated from roots of rice plants cultivated on a paddy field. Anaerobe 8, 233-246. doi: 10.1006/anae.2003.0438

Senko, J. M., Bertel, D., Quick, T. J., and Burgos, W. D. (2011). The influence of phototrophic biomass on Fe and $\mathrm{S}$ redox cycling in an acid mine drainage-impacted system. Mine Wat. Environ. 30, 38-46. doi: 10.1007/s10230-010-0123-3

Senko, J. M., Wanjugi, P., Lucas, M., Bruns, M. A., and Burgos, W. D. (2008). Characterization of $\mathrm{Fe}$ (II) oxidizing bacterial activities and communities at two acidic Appalachian coalmine drainage-impacted sites. ISME J. 2, 1134-1145. doi: 10.1038/ismej.2008.60

Senko, J. M., Zhang, G., McDonough, J. T., Brun, M. A., and Burgos, W. D. (2009). Metal reduction at low $\mathrm{pH}$ by a Desulfosporosinus species: implications for the biological treatment of acidic mine drainage. Geomicrobiol. J. 26, 71-82. doi: 10.1080/01490450802660193

Sievert, S. M., Heidorn, T., and Kuever, J. (2000). Halothiobacillus kellyi sp. nov., a mesophilic, obligately chemolithoautotrophic, sulfur-oxidizing bacterium isolated from a shallow-water hydrothermal vent in the Aegean Sea, and emended description of the genus Halothiobacillus. Int. J. Syst. Evol. Microbiol. 50, 1229-1237. doi: 10.1099/00207713-50-3-1229

Sorokin, D. Y., Tourova, T. P., Lysenko, A. M., and Muyzer, G. (2006). Diversity of culturable halophilic sulfur-oxidizing bacteria in hypersaline habitats. Microbiology 152, 3013-3023. doi: 10.1099/mic.0.29106-0

Spaulding, B. P., and Brooks, S. C. (2005). Permeable environmental leaching capsules (PELCAPs) for in situ evaluation of contaminant immobilization in soil. Environ. Sci. Technol. 39, 8912-8918. doi: 10.1021/es051379y

Stookey, L. L. (1970). Ferrozine-a new spectrophotometric reagent for iron. Anal. Chem. 42, 779 -781. doi: 10.1021/ac60289a016

Swan, B. K., Martinez-Garcia, M., Preston, C. M., Sczyrba, A., Woyke, T., Lamy, D., et al. (2011). Potential for chemolithoautotrophy among ubiquitous 
bacteria lineages in the dark ocean. Science 333, 1296-1300. doi: 10.1126/science. 1203690

Tanner, R. S. (1997). "Cultivation of bacteria and fungi," in Manual of Environmental Microbiology, eds C. J. Hurst, G. R Knudsen, M. J. McInerney, L. D. Stetzenbach, and M. V. Walter (Washington, DC: ASM Press), 52-60.

Tischler, J. S., Jwair, R. J., Gelhaar, N., Drechsel, A., Skirl, A.-M., Wiacek, C., et al. (2013). New cultivation medium for "Ferrovum" and Gallionella-related strains. J. Microbiol. Methods 95, 138-144. doi: 10.1016/j.mimet.2013.07.027

Tyson, G. W., Lo, I., Baker, B. J., Allen, E. E., Hugenholtz, P., and Banfield, B. F. (2005). Genome-directed isolation of the key nitrogen fixer Leptospirillum ferrodiazotrophum sp. nov. from an acidophilic microbial community. Appl. Environ. Microbiol. 71, 6319-6324. doi: 10.1128/AEM.71.10.6319-6324.2005

US Environmental Protection Agency (US EPA). (2006). Areas Impacted by Acidification - Acid Mine Drainage and Acid Deposition Remain Significant Problems in Region III. US Environmental Protection Agency. Available online at: http://www.epa.gov/Region3/acidification/r3_acidifcation.htm

Volant, A., Desoeuvre, A., Casiot, C., Lauga, B., Delpoux, S., Morin, G., et al. (2012). Archaeal diversity: temporal variation in the arsenic-rich creek sediments of Carnoulès Mine, France. Extremophiles 16, 645-57. doi: 10.1007/s00792-0120466-8

Wang, Q., Garrity, G. M., Tiedje, J. M., and Cole, J. R. (2007). Naïve Bayesian classifier for rapid assignment of rRNA sequences into the new bacterial taxonomy. Appl. Environ. Microbiol. 73, 5261-5267. doi: 10.1128/AEM. 00062-07

Wu, X., Wong, Z. L., Sten, P., Engblom, S., Osterholm, P., and Dopson, M. (2013). Microbial community potentially responsible for acid and metal release from an Ostrobothnian acid sulfate soil. FEMS Microbiol. Ecol. 84, 555-563. doi: 10.1111/1574-6941.12084

Yabe, S., Aiba, Y., Sakai, Y., Hazaka, M., and Yokota, A. (2011). Thermogemmatispora onikobensis gen. nov., sp. nov. and Thermogemmatispora foliorum sp. nov., isolated from fallen leaves on geothermal soils, and description of Thermogemmatisporaceae fam. nov. and Thermogemmatisporales ord. nov. within the class Ktedonobacter. Int. J. Syst. Evol. Microbiol. 61, 903-910. doi: 10.1099/ijs.0.024877-0
Yergeau, E., Newsham, K. K., Pearce, D., and Kowalchuk, G. (2007). Patterns of bacterial diversity across a range of Antarctic terrestrial habitats. Environ. Microbiol. 9, 2670-2682. doi: 10.1111/j.1462-2920.2007.01379.x

Yin, H., Cao, L., Qiu, G., Wang, D., Kellogg, L., Zhou, J., et al. (2008). Molecular diversity of $16 \mathrm{~S}$ rRNA and gyrB genes in copper mines. Arch. Microbiol. 189, 101-110. doi: 10.1007/s00203-007-0298-6

Zhang, J., Yue, T., and Yuan, Y. (2013). Alicyclobacillus contamination in the production line of kiwi products in China. PLoS ONE 8:67704. doi: 10.1371/journal.pone.0067704

Ziegler, S., Waidner, B., Itoh, T., Schumann, P., Spring, S., and Gescher, J. (2013). Metallibacterium scheffleri gen. nov., sp. nov., an alkalinizing gammaproteobacterium isolated from an acidic biofilm. Int. J. Syst. Evol. Microbiol. 63, 1499-1504. doi: 10.1099/ijs.0.042986-0

Zinger, L., Shahnavaz, B., Baptist, F., Geremia, R., and Choler, P. (2009). Microbial diversity in alpine tundra soils correlates with snow cover dynamics. ISME J. 3, 850-859. doi: 10.1038/ismej.2009.20

Conflict of Interest Statement: The authors declare that the research was conducted in the absence of any commercial or financial relationships that could be construed as a potential conflict of interest.

Received: 27 February 2014; accepted: 23 April 2014; published online: 14 May 2014. Citation: Brantner JS, Haake ZJ, Burwick JE, Menge CM, Hotchkiss ST and Senko JM (2014) Depth-dependent geochemical and microbiological gradients in Fe(III) deposits resulting from coal mine-derived acid mine drainage. Front. Microbiol. 5:215. doi: 10.3389/fmicb.2014.00215

This article was submitted to Microbiological Chemistry, a section of the journal Frontiers in Microbiology.

Copyright (c) 2014 Brantner, Haake, Burwick, Menge, Hotchkiss and Senko. This is an open-access article distributed under the terms of the Creative Commons Attribution License (CC BY). The use, distribution or reproduction in other forums is permitted, provided the original author(s) or licensor are credited and that the original publication in this journal is cited, in accordance with accepted academic practice. No use, distribution or reproduction is permitted which does not comply with these terms. 